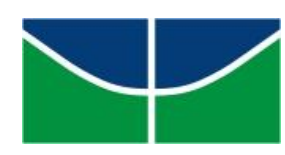

UNIVERSIDADE DE BRASILIA

INSTITUTO DE CIÊNCIAS HUMANAS

DEPARTAMENTO DE GEOGRAFIA

MESTRADO EM GEOGRAFIA

\title{
UTILIZAÇÃO DE RESTITUIÇÃO AEROFOTOGRAMÉTRICA PARA ANÁLISE DA INFLUÊNCIA DAS ALTERAÇÕES DA REDE DE DRENAGEM E DESENVOLVIMENTO DE VOÇOROCAS DEVIDO A URBANIZAÇÃO NO MUNICÍPIO DE JACAREÍ (SP)
}

\author{
Anesmar Olino de Albuquerque \\ Orientador: Prof. Dr. Renato Fontes Guimarães \\ Coorientador: Prof. Dr. Osmar Abílio de Carvalho Júnior \\ Dissertação de Mestrado
}

Brasília, dezembro de 2015 


\author{
UNIVERSIDADE DE BRASILIA \\ INSTITUTO DE CIÊNCIAS HUMANAS \\ DEPARTAMENTO DE GEOGRAFIA \\ MESTRADO EM GEOGRAFIA
}

\title{
UTILIZAÇÃO DE RESTITUIÇÃO AEROFOTOGRAMÉTRICA PARA ANÁLISE DA INFLUÊNCIA DAS ALTERAÇÕES DA REDE DE DRENAGEM E DESENVOLVIMENTO DE VOÇOROCAS DEVIDO A URBANIZAÇÃO NO MUNICÍPIO DE JACAREÍ (SP)
}

\begin{abstract}
Anesmar Olino de Albuquerque
Dissertação de Mestrado submetida ao Departamento de Geografia da Universidade de Brasília, como parte dos requisitos necessários para obtenção do Grau de Mestre em Geografia, área de concentração Gestão Ambiental e Territorial.

Aprovada por:
\end{abstract}

Prof. Dr. Renato Fontes Guimarães

Universidade de Brasília - Departamento de Geografia

Orientador

Prof. Dr. Osmar Abílio de Carvalho Júnior

Universidade de Brasília - Departamento de Geografia

Coorientador

Prof. Dr. Éder de Souza Martins

EMBRAPA/DF

Examinador Externo

Profa. Dra. Nóris Costa Diniz

Universidade de Brasília - Departamento de Geologia

Examinador Externo

Prof. Dr. Leonardo José Cordeiro Santos

Universidade Federal do Paraná - Departamento de Geografia

Examinador Externo

Brasília, 11 dezembro de 2015 


\section{FICHA CATALOGRÁFICA}

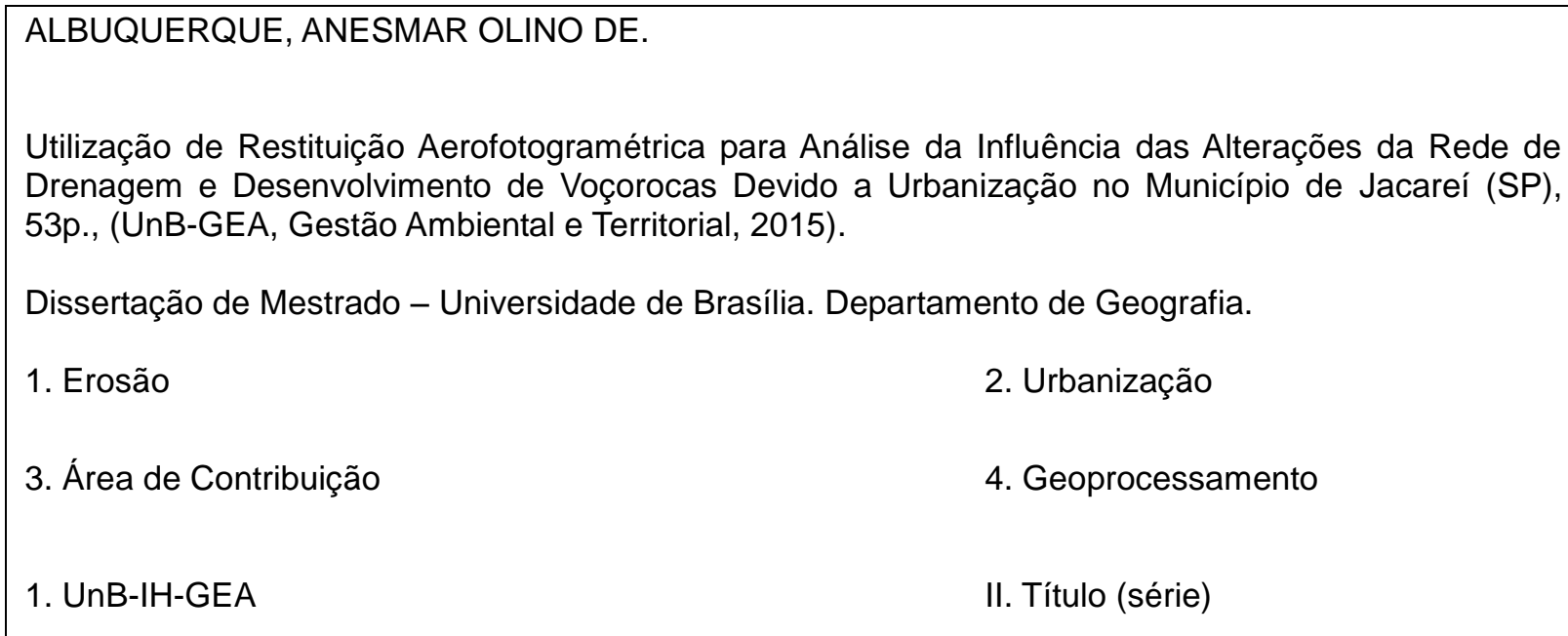

\section{REFERÊNCIA BIBLIOGRÁFICA}

ALBUQUERQUE, A. O. Utilização de Restituição Aerofotogramétrica para Análise da Influência das Alterações da Rede de Drenagem e Desenvolvimento de Voçorocas Devido a Urbanização no Município de Jacareí (SP). 2015. 53 f. Dissertação (Mestrado em Geografia) - Instituto de Ciências Humanas, Universidade de Brasília, Distrito Federal, 2015.

\section{CESSÃO DE DIREITOS}

Nome do autor: Anesmar Olino de Albuquerque

Título da dissertação: Utilização de Restituição Aerofotogramétrica para Análise da Influência das Alterações da Rede de Drenagem e Desenvolvimento de Voçorocas Devido a Urbanização no Município de Jacareí (SP).

Grau/ano: Mestre/2015

É concedida à Universidade de Brasília permissão para reproduzir cópias desta dissertação e emprestar ou vender tais cópias somente para propósitos acadêmicos e científicos. O autor reserva outros direitos de publicação e nenhuma parte desta dissertação pode ser reproduzida sem a autorização por escrito do autor. 


\section{AGRADECIMENTOS}

Agradeço a Deus, pelo dom da vida, por me proporcionar incríveis oportunidades e por colocar na minha vida pessoas tão especiais.

Aos meus pais, em especial a minha querida mãe, Guilhermina, que sempre foi minha maior inspiração, aos meus irmãos: Antônio, Célia e Selma, pelo apoio e por acreditarem em mim.

À Saiaka que, mesmo com as dificuldades de desenvolver seu próprio trabalho, sempre me incentivou e me ajudou e por ser uma maravilhosa companheira.

Ao meu orientador, Prof. Dr. Renato Fontes Guimarães, que sempre se dispôs a ajudar, tendo importante participação em todo trabalho como um grande mestre. Agradeço ainda pela confiança de me receber em sua residência para ensinamentos, e pela amizade construída, espero que seja duradoura.

Ao meu coorientador, Prof. Dr. Osmar Abílio de Carvalho Júnior, pela imensa contribuição no trabalho, que, mesmo com inúmeras atribuições, contribuiu de forma significativa, principalmente na etapa final, agradeço pela amizade e pela competência.

Ao professor Dr. Roberto Arnaldo Trancoso Gomes, que colaborou muito ao longo do trabalho e esclareceu diversas dúvidas, mesmo estando longe, via videoconferência, agradeço pela amizade e consideração.

Aos amigos e amigas do Laboratório de Sistemas e Informações Espaciais - LSIE: Nathalia Costa, Vitor Paiva, Victor Hugo, Pedro Coutinho, Marcus Fábio, Verônica Ramos, Sandro Oliveira, que de uma forma ou outra também puderam contribuir para a realização desse trabalho. 


\section{Resumo}

Os processos de urbanização têm provocado modificações no comportamento do escoamento superficial, especialmente pela impermeabilização do solo causada por pavimentações e edificações. As superfícies impermeabilizadas reduzem a infiltração das águas das chuvas e aumentam o escoamento superficial tanto em volume quanto em velocidade. Essas modificações aliadas ao planejamento inadequado ou mesmo a falta dele, faz com que os processos erosivos sejam desencadeados. Neste intuito, a modelagem matemática tem sido aplicada para identificar o papel da urbanização na intensificação dos processos erosivos. A modelagem matemática é baseada em Modelo Digital de Superfície (MDS) e Modelo Digital de Terreno (MDT). Com isso, o objetivo do presente trabalho é desenvolver uma metodologia que possibilita identificar se o processo de urbanização no município de Jacareí (SP) está influenciando no desencadeamento dos processos erosivos. A metodologia baseou-se nas seguintes fases: construção do MDS (pós-urbanização); construção do MDT (pré-urbanização); modelagem hidrológica pós e pré-urbana. Os modelos digitais pré e pós-urbanos foram construídos a partir de técnicas fotogramétricas utilizando os módulos MATCH-T DSM e DTMaster, ambos do sistema fotogramétrico INPHO. A aplicação de técnicas fotogramétricas resultou em modelos digitais consistentes e realistas. Os resultados obtidos demonstraram uma clara influência da urbanização na deflagração dos processos erosivos, onde a área de contribuição teve um aumento de uma a três ordens de grandeza.

Palavras chave: erosão, escoamento superficial, modelo digital de superfície e de terreno, restituição fotogramétrica, MATCH-T DSM, DTMaster. 
Abstract

Urbanization processes have caused changes in the runoff behavior, especially by soil sealing caused by paving and buildings. The impermeable surfaces reduce infiltration of rainwater runoff and increase both volume and speed. These changes combined with the inadequate planning or even the lack of it, causes erosion could be undertaken. There for, we have developed methodologies using mathematical modeling to identify urban processes have triggered the erosion. Mathematical modeling is based on Digital Surface Model (DSM) and Digital Terrain Model (DTM). Thus, the objective of this study is to develop a methodology to identify whether the process of urbanization in the city of Jacarei (SP) is influencing the onset of erosion. The methodology was based on the following phases: construction of the MDS (post-urbanization); construction of MDT (pre-urbanization); post hydrological modeling and pre-urban. The pre- and post-urban digital models were built from photogrammetric techniques using the MATCH-T DSM and DTMaster modules, both of INPHO photogrammetric system. The application of photogrammetric techniques resulted in consistent and realistic digital models. The results demonstrated a clear influence of urbanization on the outbreak of erosion in which the contribution area had an increase of around 1 to 3 magnitudes.

Keywords: erosion, runoff, digital surface model and terrain, photogrammetric restitution, MATCH-T DSM, DTMaster. 


\section{SUMÁRIO}

1 - INTRODUÇÃO

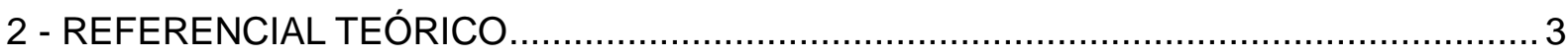

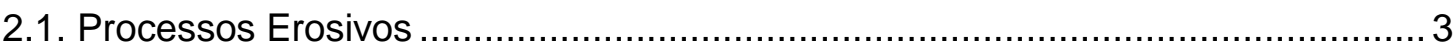

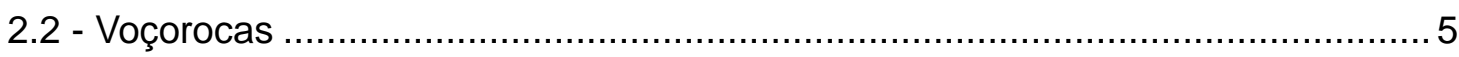

2.3. Modelo Digital de Terreno (MDT) e de Superfície (MDS) ………….................. 6

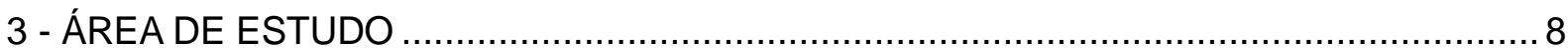

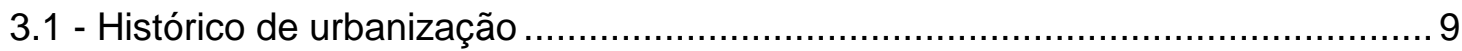

3.2 - Clima

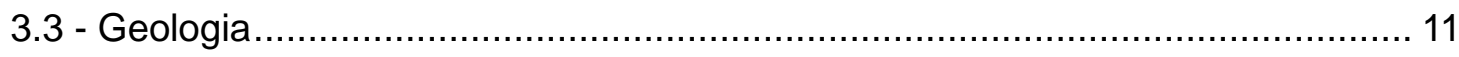

3.4 - Geomorfologia

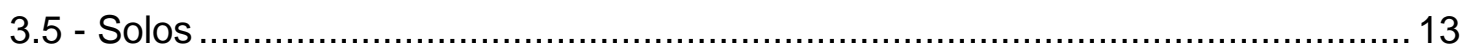

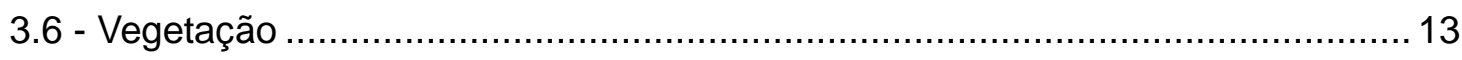

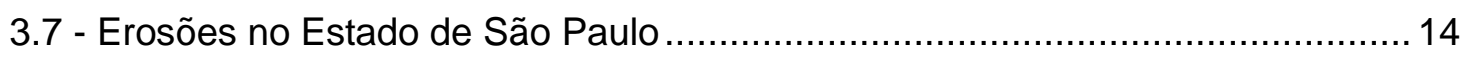

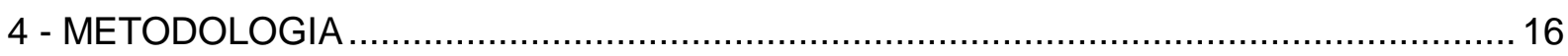

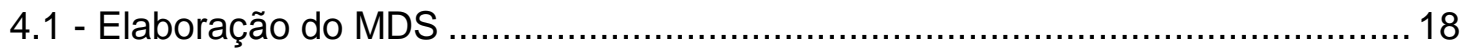

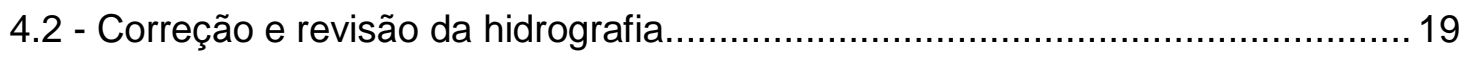

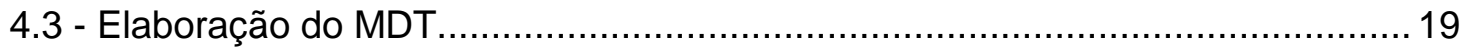

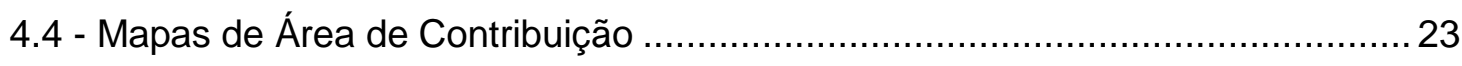

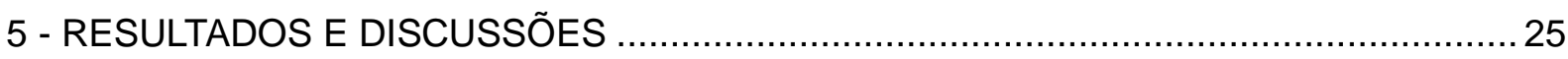

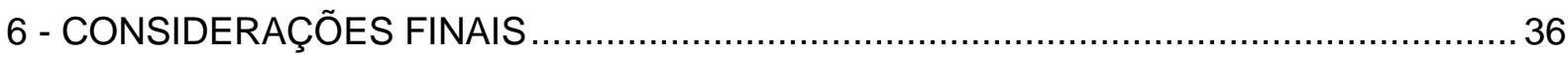

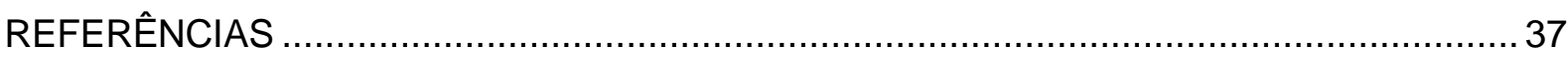




\section{LISTA DE FIGURAS}

Figura 2. 1- Comparação entre os hidrogramas de uma bacia rural e depois de urbanizada (Fonte: adaptado de Tucci, 2008) .............................................. 3

Figura 3. 1 - Mapa de localização do município de Jacareí/SP...............................................8

Figura 3. 2 - Mapa de localização da área de estudo dentro da região urbana de

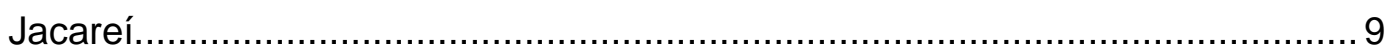

Figura 3. 3 - Crescimento Populacional no Município de Jacareí-SP (IPEA, 2014) .............. 10

Figura 3. 4 - Curva de regressão da cobertura florestal do Estado de São Paulo (VICTOR et al., 2005)....................................................................... 14

Figura 3. 5 - Mapa de suscetibilidade a erosões no Estado de São Paulo (IPT, 1997)......... 15

Figura 4. 1 - Fluxograma com as etapas realizadas durante a aplicação da metodologia.....17

Figura 4. 2 - Inconsistências no MDS antes (A) e depois da correção (B) .......................... 19

Figura 4. 3 - Relevo sombreado com parte editada (A) e relevo sombreado com parte editada, linhas de apoio (azul) e curvas de nível (cinza) (B)........................... 20

Figura 4.4 - Perfis topográficos da nuvem de pontos com parte filtrada. ........................... 20

Figura 4. 5 - Imagem do Google Earth de área antes da ocorrência de voçoroca.................21

Figura 4. 6 - Ortofoto $(\mathrm{A})$ e relevo sombreado $(\mathrm{B})$ antes da filtragem de voçoroca...............21

Figura 4.7 - Ortofoto (A) e relevo sombreado (B) após filtragem de voçoroca.....................22

Figura 4. 8 - Ortofoto com as curvas de nível (esquerda) e MDS (direita), antes da

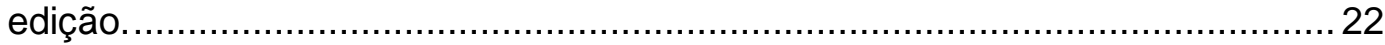

Figura 4. 9 - Ortofoto com as curvas de nível (A) e MDT (B) após filtragem da vegetação

Figura 4. 10 - Perfis topográficos dos erros residuais antes $(A)$ e depois $(B)$ da correção.

Figura 4. 11 - Erros residuais antes $(A)$ e depois $(B)$ da correção. 23

Figura 5. 1 - Ocorrência de voçorocas dentro da área de pesquisa (1). Fotografia de voçoroca em processo de recuperação (2) e fotografia de voçoroca (3). .25

Figura 5. 2 - MDS pós-urbano (A) e MDT pré-urbano (B), (exibição de superfície hipsométrica com relevo sombreado) e respectivos perfis topográficos.............27

Figura 5. 3 - Mapa de área de contribuição pós-urbano (A) e pré-urbano (B). 28

Figura 5. 4 - Relevo sombreado pós e pré-urbano (A-B); exibição do perfil topográfico da nuvem de pontos pós e pré-urbano (C-D); e perfil com exibição hipsométrica e relevo sombreado pós e pré-urbanos (E-F).

Figura 5.5 - Relevo sombreado pós e pré-urbano (A-B) de área com vegetação; exibição do perfil topográfico da nuvem de pontos pós e pré-urbano (C-D); e perfil com exibição hipsométrica e relevo sombreado pós e pré-urbanos (E-F)...................30 
Figura 5. 6 - Mapa de alteração da área de contribuição. Os círculos representam áreas que apresentaram aumento de fluxo e desenvolveram voçorocas e os quadrados representam áreas em que o fluxo diminuiu e não desenvolveram voçorocas.

Figura 5. 7 - O gráfico representa os valores de fluxo dos períodos pré e pós-urbano. Os círculos e quadrados do gráfico também estão representados na Figura 5.6 .... 32

Figura 5.8 - Localização da área submetida a análise multitemporal. 33

Figura 5. 9 - Imagens do Google Earth com a evolução da voçoroca em diferentes períodos: a) setembro/2008; b) maio/2013; c) fevereiro/2014 e d) fevereiro/2015. O círculo em vermelho está representado na Figura 5.10.........33

Figura 5. 10 - Fotografia com destaque na encosta e pontos coletados para análise...... 34

Figura 5. 11 - Mapa de alteração da área de contribuição da encosta urbana com pontos coletados para análise. 


\section{LISTA D E TABELAS}

Tabela I - Configuração dos parâmetros do MATCH-T DSM. …………………………..... 18

Tabela II - Valores de área de contribuição e declividade dos pontos da encosta urbana

(Figura 5.11) 


\section{LISTA DE SIGLAS E ABREVIATURAS}

CX - Cambissolos Háplicos

CLU - Contrato de Licença e Uso

$\mathrm{CH}$ - Cambissolos Húmicos

Cwa - Clima subtropical de altitude, com inverno seco e verão quente

Cwb - Clima subtropical de altitude, com inverno seco e verão ameno

DAEE - Departamento de Águas e Energia Elétrica

E - Espodossolos

EMPLASA - Empresa Paulista de Planejamento Metropolitano

ENE - Leste-Norte-Leste

GM - Gleissolos Melânicos

GNSS - Global Navigation Satellite System

GRID - Global Resource Information Database

IMU - Inertial Measurement Unit

INPE - Instituto Nacional de Pesquisas Espaciais

IPT - Instituto de Pesquisas Tecnológicas

km - Kilômetro

$\mathrm{m}$ - Metro

MDS - Modelo Digital de Superfície

MDT - Modelo Digital de Terreno

$\mathrm{N}$ - Norte

LASER - Ligth Amplification by Stimulated Emission of Radiation

LIDAR - Light Detection and Ranging

LV - Latossolos Vermelhos

LVA - Latossolos Vermelho-Amarelos

PVA - Argissolos Vermelho-Amarelos

RADAR - Radio Detection and Ranging

RCSB - Rift Continental do Sudeste do Brasil

RGB - Red, Green and Blue

TIN - Triangular Irregular Network 


\section{1 - INTRODUÇÃO}

A crescente demanda por áreas de expansão urbana aliada a falta de planejamento faz com que o crescimento das cidades ocorra de forma desordenada, o que acarreta uma série de danos sociais e ambientais. As cidades são consideradas um dos maiores exemplos de degradação ambiental, comprometendo a segurança e a qualidade de vida das pessoas que a habitam (OLIVEIRA \& HERRMANN, 2006).

É possível verificar que o crescimento de zonas urbanizadas tem provocado um aumento significativo de superfícies impermeabilizadas, que reduzem a infiltração da água da chuva e aumentam o escoamento superficial, alterando todo o ciclo hidrológico e possibilitando o surgimento de erosões (GURNELL et al., 2007; PORTO et al., 2004).

As alterações do escoamento superficial devido à urbanização podem afetar tanto a rede de drenagem que em casos extremos o pico da cheia pode chegar a ser seis vezes maior do que em condições naturais (PORTO et al., 2009). Os processos erosivos em áreas urbanas geralmente ocorrem em regiões que recebem a maior parte do escoamento, muitas vezes, de uma cidade ou bairros inteiros. Bertoni e Lombardi Neto (1990) destacam que algumas características naturais do terreno podem exercer grande influência no desenvolvimento de erosões, como a declividade, o comprimento da vertente e a permeabilidade, estrutura, densidade e textura do solo onde vai ocorrer o escoamento.

A modelagem matemática vem se destacando como principal ferramenta de análise dos processos de evolução do relevo, contribuindo na simulação de cenários e na identificação dos principais fatores condicionantes dos processos erosivos (RAMOS et al., 2002). O uso de modelos torna possível a elaboração de mapas derivados com informações topográficas e hidrológicas confiáveis. A qualidade, precisão e confiabilidade dos modelos estão diretamente relacionadas à qualidade do dado de entrada utilizado para a sua obtenção (LEMAIRE, 2008; KAREL et al., 2006).

As ferramentas de geoprocessamento têm impulsionado o desenvolvimento de métodos automáticos para obtenção de dados espaciais. A rapidez e eficiência de processamento em ambientes computacionais têm contribuído significativamente nas diversas pesquisas relacionadas às dinâmicas topográficas (VALERIANO e CARVALHO JÚNIOR, 2003). Sendo hoje possível extrair informações topográficas e da superfície dos objetos sobrepostos a esta topografia, a partir de aerolevantamentos. Num mesmo aerolevantamento, por exemplo, é possível extrair informações da superfície do terreno ou topografia (os chamados modelos digitais de terreno - MDT), como também a altura das estruturas sobrepostas a esta topografia (os chamados modelos digitais de superfície MDS). 
Neste contexto, nos últimos anos as pesquisas ambientais aumentaram significativamente no Brasil e no mundo de forma quantitativa e qualitativa, principalmente nas análises de degradação da natureza praticadas pela ação do homem e nas medidas necessárias para minimizar tal degradação (FRITZEN, 2011). O uso racional do solo exige um planejamento adequado com mecanismos que permitam uma avaliação mais precisa de áreas sensíveis a erosões. Nesse contexto, a drenagem urbana objetiva estudar o escoamento do excesso das águas precipitadas, que podem causar inundações e prejuízos financeiros diretos para a população, para fora da área urbanizada (PORTO et al., 2009).

A importância de estudos relacionados à topografia e a dinâmica dos processos erosivos está na possibilidade de implementação de medidas que visem à recuperação de áreas degradadas bem como na prevenção desses processos. A utilização de modelos hidrológicos é de fundamental importância para análises relacionadas ao comportamento e alterações do escoamento superficial. Em ambientes urbanos o uso de modelagem matemática torna possível a identificação de áreas sensíveis à ocorrência de processos erosivos devido à concentração de fluxo e permite análises quanto às mudanças na rede de drenagem (CARVALHO JÚNIOR et al., 2010; MARK et al., 2004).

O presente trabalho tem como objetivo principal analisar a influência do processo de urbanização no desenvolvimento de processos erosivos, utilizando modelos digitais de superfície (MDS) e do terreno (MDT) construídos com uso de técnicas aerofotogramétricas e fotografias digitais com alta resolução espacial. Os objetivos específicos são: (a) desenvolvimento do MDS e do MDT com o uso do sistema fotogramétrico INPHO; (b) análise dos parâmetros hidrológicos através da simulação dos cenários pré e pós-urbano. 


\section{2 - REFERENCIAL TEÓRICO}

\section{1 - Processos Erosivos}

A água das chuvas é o principal agente modelador da paisagem em ambientes tropicais e sua ação erosiva é bastante agravada em regiões com índices pluviométricos elevados e concentrados durante alguns meses do ano (GUERRA, 2011). O escoamento da água da chuva é afetado diretamente pelas características naturais do solo e o tipo de ocupação antrópica. Em ambientes urbanizados, a impermeabilização causada pela pavimentação das ruas, edificações e canalização de águas pluviais provoca a redução da infiltração das águas das chuvas e um aumento do volume do escoamento superficial e da velocidade do fluxo (POFF et al., 2006). Portanto, a maior parte da água precipitada escoa em direção aos canais fluviais causando picos de vazão, que são atingidos em um espaço menor de tempo e com menores quantidades de precipitação (BOOTH, 1991; PORTO et al., 2009; BOTELHO e SILVA, 2010; CARDOSO NETO, 2010). Tucci (2008) apresenta um hidrograma para demonstrar as alterações de uma bacia hidrográfica após a urbanização (Figura 2.1):

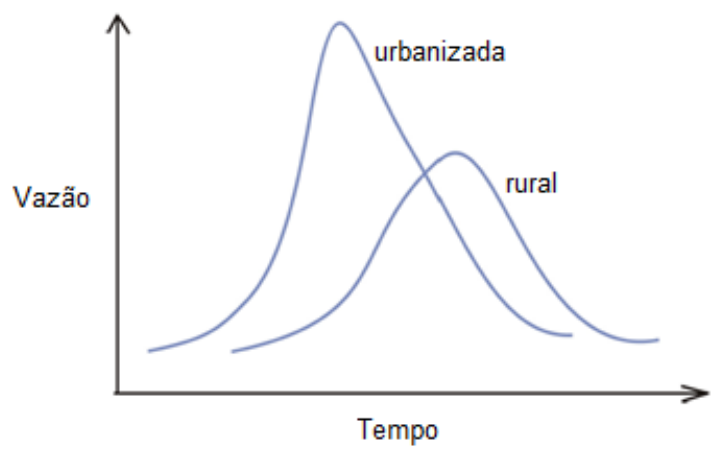

Figura 2. 1- Comparação entre os hidrogramas de uma bacia rural e depois de urbanizada (Fonte: adaptado de Tucci, 2008).

A erosão causa a desagregação, transporte e deposição de partículas do solo, sua ocorrência está diretamente relacionada com os fatores controladores, como a erosividade da chuva, propriedades do solo, cobertura vegetal e características das encostas (GUERRA, 1995; BERTONI \& LOMBARDI NETO, 1990). A interação desses fatores pode definir a predisposição a ocorrência de processos erosivos em determinada região.

A erosão hídrica é um processo natural que ocorre em quase toda superfície terrestre e as atividades humanas tem intensificado muito este processo. A aceleração dos processos erosivos muitas vezes está associada ao desmatamento e cultivo agrícola de forma inadequada ou crescimento de zonas urbanizadas sem o devido planejamento (KERTZMAN 
et al., 1995; CARVALHO \& DINIZ, 2007).

O primeiro estágio da erosão hídrica inicia no momento em que as gotas de chuva (splash) começam a bater nos solos desagregando partículas, sendo responsável pelo rompimento e transporte de partículas (BERTONI \& LOMBARDI NETO, 1990; GUERRA, 1999; BIGARELLA, 2003; BECKER \& SANTOS, 2007). Segundo Guerra (1999), as gotas de chuvas provocam a quebra dos agregados em partículas menores que podem preencher espaços menores no solo causando a impermeabilização da superfície do solo, o que pode aumentar o fluxo de águas superficiais, devido à diminuição da capacidade de infiltração do solo. Em ambientes naturais, os efeitos erosivos causados pelo splash podem ser minimizados significativamente mantendo-se a cobertura vegetal do solo, já em ambientes urbanos o impacto das gotas de chuvas tem efeito erosivo reduzido por conta da compactação dos solos pelos elementos urbanos.

No momento em que o solo tem a sua capacidade de armazenamento de água saturada ou exceda a sua capacidade de infiltração, as águas acumuladas na superfície formam poças e começam a se deslocar relevo abaixo dando início ao escoamento superficial (GUERRA, 1999). A perda de parcelas de solo pelo escoamento superficial vai depender diretamente da velocidade e agitação dos sedimentos dentro do fluxo (GUERRA, 1995).

Segundo Nearing et al. (1989), o surgimento de processos erosivos devido a eventos chuvosos está diretamente relacionado à taxa de desprendimento que sofrerá variações de acordo com o tamanho das partículas e a capacidade de transporte pelo escoamento superficial. A presença de vegetação pode servir como redutor de energia e velocidade do fluxo superficial (HORTON, 1945).

O escoamento concentrado das águas das chuvas em camadas subsuperficiais de terreno afeta a erodibilidade do solo e pode interferir em possíveis danos erosivos não apenas nos canais onde o fluxo corre como também na estrutura que se encontra acima que pode ceder e se transformar numa voçoroca (GUERRA, 1995).

A água acumulada na superfície inicia um deslocamento pela encosta através de um fluxo difuso ou escoamento em lençol, ocasionando uma erosão laminar (GUERRA, 1999). Uma das principais características do escoamento em lençol é a capacidade de retirada de camada superficial de forma quase homogênea, que pode ser notada pela exposição de raízes.

O desenvolvimento do fluxo linear ocorre com a concentração e aumento de profundidade do fluxo de água e a formação de canais de escoamento. $O$ atrito entre as partículas no seu interior inicia as primeiras erosões (GUERRA, 1999). A erosão linear que pode ocorrer nessa etapa é responsável pelo desprendimento e transporte de partículas conforme as condições hidráulicas do escoamento (FOSTER et al., 1985). 
Horton (1945) relaciona o desenvolvimento de ravinas com a fase posterior da erosão liminar analisando-as como integrantes de um sistema de drenagem. Ele considera que o volume de água que inicia um deslocamento no topo da encosta através de lençol evolui para ravinas quando a concentração de fluxo é canalizada e tem seu poder erosivo aumentado numa distância crítica do topo da encosta, tornando-se capaz de transportar partículas do solo.

\section{2 - Voçorocas}

Bertoni e Lombardi Neto (1990) consideram as voçorocas como as mais impressionantes formas de erosão devido à imensidão das cavidades erodidas e caracteriza sua formação pela grande concentração de fluxos de água e transporte de grande quantidade de sedimentos de um mesmo canal. Dentre os diversos tipos de processos erosivos, as voçorocas são consideradas a forma mais agressiva e se caracterizam por depressões profundas e paredes laterais de elevada declividade

As três principais formas de desenvolvimento de voçorocas, segundo Guerra (1995) estão relacionadas: a) à evolução de ravinas num determinado tipo de solo, a partir do momento em que o volume do escoamento superficial torna-se mais degradante e provoca o aprofundamento e alargamento da base e laterais das ravinas transportando os sedimentos para as áreas mais baixas da encosta; b) pela evolução no fluxo e na ação erosiva de canais onde ocorrem escoamentos subsuperficiais, há um aumento do diâmetro de dutos e o colapso da estrutura acima deles, surgindo assim grandes voçorocas; e c) pelo escoamento superficial concentrado no interior da cicatriz de deslizamentos de terras, uma vez que os sedimentos já se encontram relativamente soltos e propícios para o transporte pelo fluxo de água, conforme descrição de Vittorini apud Guerra (1995).

A maioria dos processos erosivos do tipo voçoroca estão associados à intervenção humana, principalmente por conta de desmatamentos, atividades agrícolas ineficientes, crescimento de zonas urbanizadas sem o devido planejamento e outras formas de uso do solo (PONÇANO \& PRANDINI, 1987). Normalmente sua ocorrência está relacionada a grandes prejuízos financeiros, sociais e ambientais e em ambientes urbanizados o problema é ainda mais crítico pelo risco de perda de vidas, principalmente de habitantes que ocupam regiões periféricas das cidades (CARVALHO \& DINIZ, 2007). 


\section{3 - Modelo Digital de Terreno (MDT) e de Superfície (MDS)}

A representação da modelagem tridimensional do terreno ou da superfície, a partir de modelos digitais, é fundamental para explicação ou previsão de fenômenos espaciais que podem ser aplicados em projetos de engenharia, análises ambientais, sensoriamento remoto, geofísica, geografia, hidrologia, geomorfologia entre outros (HSIA e NEWTON, 1999; PULIGHE e FAVA, 2013).

Os dados de um MDT ou MDS normalmente estão dispostos num espaçamento irregular representados pelas coordenadas $X, Y$, e o parâmetro a ser modelado é descrito por Z. A estrutura de dados pode estar organizada em grade regular (GRID) ou de maneira irregular num formato de malha triangular conhecida como TIN (Triangular Irregular Network) (FELGUEIRAS, 2001). A estruturação em grade regular se tornou dominante nos modelos digitais pela compatibilidade de diversas aplicações e simplicidade nas análises (HUTCHINSON et al., 2011).

De acordo com Weidner e Förstner (1995), um MDT é composto por pontos correspondentes apenas à topografia do relevo e o MDS é composto por pontos que representam a superfície do terreno e elementos que se encontram acima dele, como a cobertura vegetal e edificações.

Os principais métodos para obtenção de modelos digitais utilizados estão relacionados a dados obtidos por: levantamento de campo com equipamentos para medições diretamente na superfície do solo; curvas de nível digitalizadas e pontos cotados de cartas topográficas; sensores ativos como RADAR e varredura LASER; e dados fotogramétricos oriundos de imagens aéreas ou orbitais.

Algumas regiões apresentam limitações quanto ao uso de determinado dado para geração de modelos digitais, como em ambientes urbanos e em florestas densas, que até algum tempo atrás apenas a tecnologia LIDAR obtinha bons resultados. A evolução da fotogrametria vem mudando esse cenário como foi destacado em estudo apresentado por Haala et al. (2010). Nele, os autores avaliaram o potencial de técnicas fotogramétricas para geração de MDS, utilizando imagens digitais de alta resolução espacial e compararam esse modelo com outro gerado com o uso de tecnologia LIDAR. O resultado obtido foi claramente positivo, uma vez que a nuvem de pontos em 3D apresentou qualidade comparável a obtida pelo laser, apesar de ainda estarem comprometidos a possíveis erros.

As técnicas fotogramétricas evoluíram muito nos últimos anos, principalmente depois do surgimento das câmeras digitais, que revolucionou a fotogrametria tradicional e 
consolidou essa tecnologia como fundamental ferramenta na elaboração de mapeamentos e de diversos planejamentos relacionados ao uso da terra (RIBEIRO, 2002). Os avanços tecnológicos ocorridos junto à fotogrametria proporcionaram um crescimento surpreendente tanto na evolução dos equipamentos de aquisição de imagens, quanto nos instrumentos utilizados para sua restituição (TEMBA, 2000; GRUEN \& LI, 2002; HÖHLE, 2009).

As pesquisas desenvolvidas utilizando técnicas fotogramétricas apresentam correlações com diversas áreas e habilidades como planejamento urbano, visão computacional, computação gráfica, cartografia, engenharias, entre outras (COSTANTINO \& ANGELINI, 2011).

A construção de modelos digitais baseados em dados fotogramétricos necessita de algoritmos adequados e específicos para que o produto tridimensional alcance a consistência pretendida, alguns desses algoritmos foram testados por Haala (2013), que concluiu que existe um número crescente de softwares fotogramétricos para obtenção de MDS com confiabilidade e precisão satisfatória. 


\section{3 - ÁREA DE ESTUDO}

O município de Jacareí se localiza na parte leste do Estado de São Paulo entre as Serras da Mantiqueira e do Mar, região conhecida como Vale do Paraíba Paulista (Figura 3.1). Localizado entre os paralelos $23^{\circ} 18^{\prime}$ ao sul e $45^{\circ} 58^{\prime}$ a oeste e altitude média de 580 metros acima do nível do mar, o município se estende pela Via Dutra, principal rodovia de ligação entre as duas principais metrópoles brasileiras, Rio de Janeiro e São Paulo. A área de estudo engloba os bairros: Cidade Salvador, Jardim Santa Mariana, Parque dos Príncipes, Conjunto São Benedito e Vila Zezé (Figura 3.2). A área foi escolhida por dispor de topografia adequada para aplicação da modelagem e por apresentar de voçorocas em áreas urbanas.

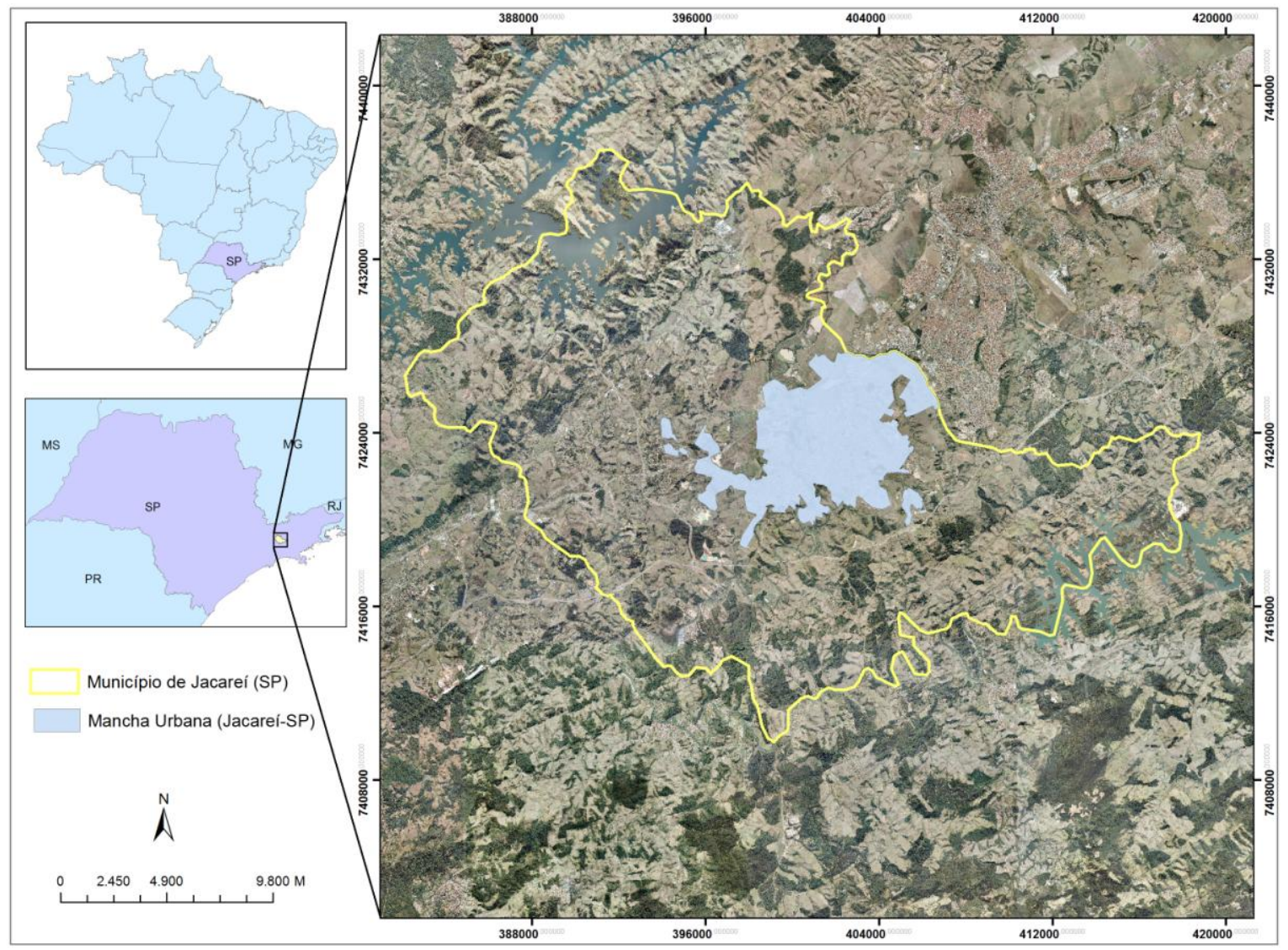

Figura 3. 1 - Mapa de localização do município de Jacareí/SP. 


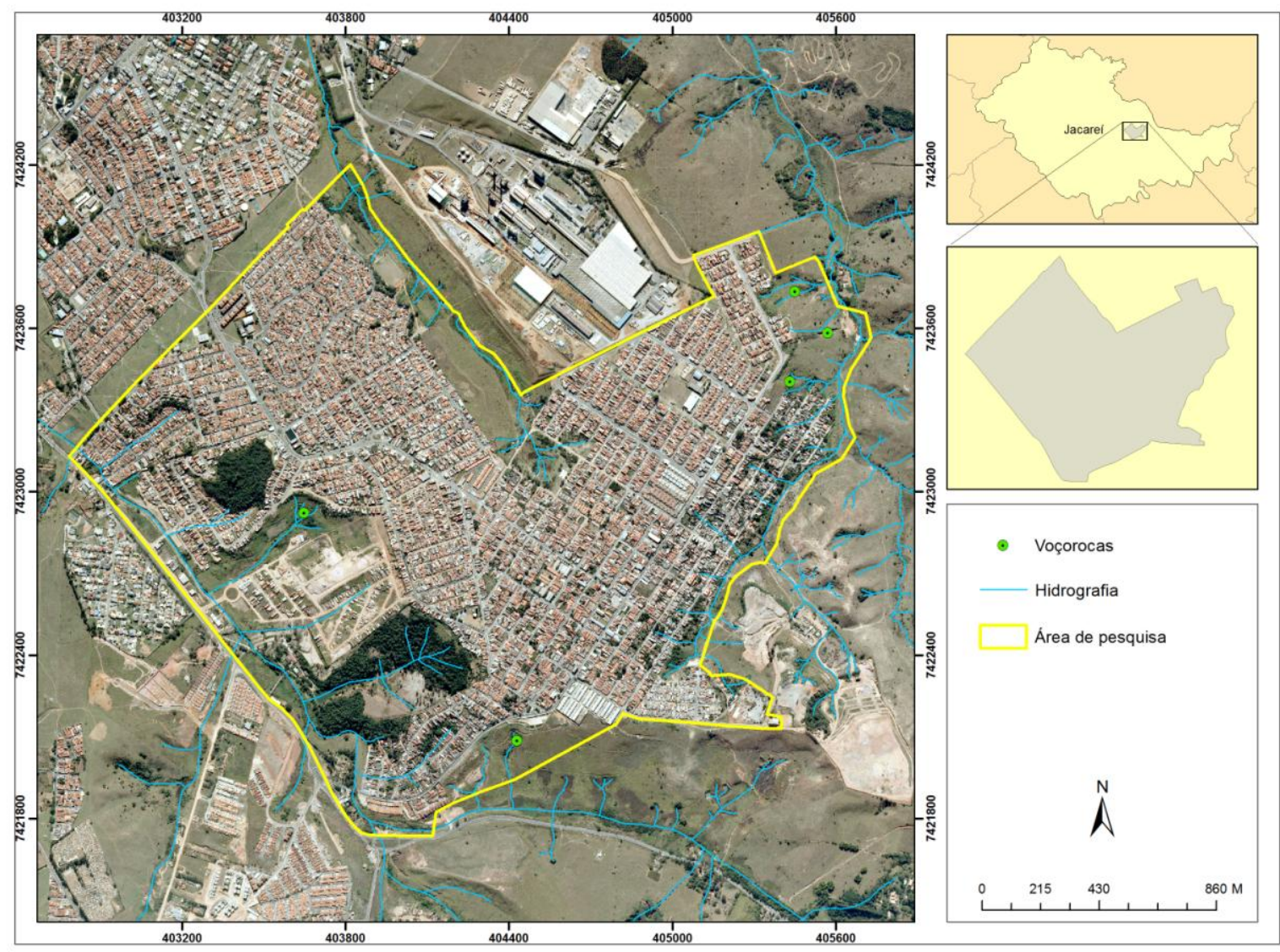

Figura 3. 2 - Mapa de localização da área de estudo dentro da região urbana de Jacareí.

\section{1 - Histórico de urbanização}

O município de Jacareí surgiu a partir de um pequeno povoado em 1652, foi elevado a condição de Vila em 1653 e se tornou cidade apenas em 3 de abril de 1849. Durante os séculos XVII e XVIII, servia apenas de passagem aos mineradores que se deslocavam para as Minas Gerais, vivendo basicamente do comércio que abastecia aqueles que se dirigiam à região de mineração (PREFEITURA MUNICIPAL DE JACAREÍ, 2014).

Seu crescimento urbano iniciou-se efetivamente com a ascensão do café no Vale do Paraíba a partir do século XIX e teve grande aceleração no período industrial devido à instalação de um importante e diversificado polo industrial. De acordo com Reschilian (2005), historicamente o processo de urbanização da região do Vale do Paraíba Paulista está associado aos sistemas de transportes instalados na região, como: a ferrovia do século XIX, as rodovias Presidente Dutra, Ayrton Senna, Dom Pedro I e Carvalho Pinto.

Similarmente ao processo de urbanização das cidades brasileiras, o município de Jacareí apresentou elevado crescimento populacional urbano no período de 1940 a 2010 . 
A Figura 3.3 proporciona uma melhor visualização da evolução da população urbana e rural no município ao longo do século XX, em especial o período pós 1970, que apresentou queda da população rural e acelerado crescimento populacional urbano.

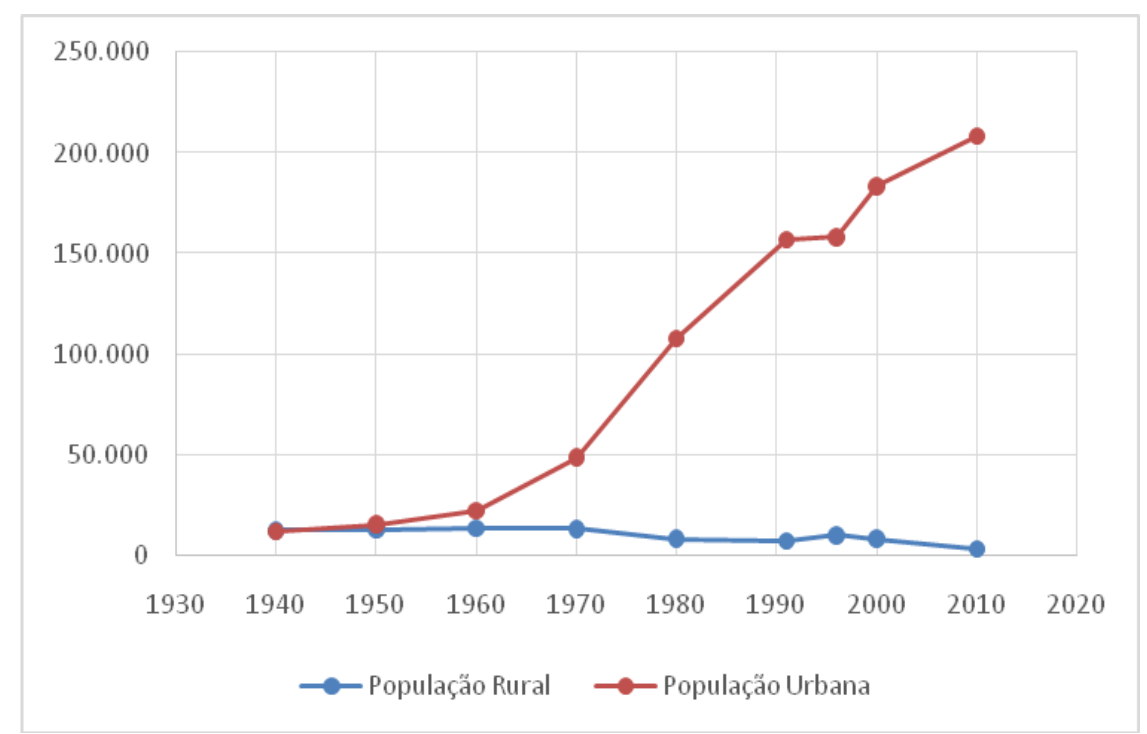

Figura 3. 3 - Crescimento Populacional no Município de Jacareí-SP (IPEA, 2014).

No município de Jacareí a expansão urbana muitas vezes ocorre em áreas que deveriam ser limitantes ao processo de urbanização, como as encostas e as áreas de várzeas que são regiões com grande susceptibilidade a inundações, escorregamentos e erosões. Atualmente, o município de Jacareí se encontra em uma região com intenso processo de conurbação urbana, como nos trechos Jacareí - São José dos Campos Caçapava; Taubaté - Pindamonhangaba e Aparecida - Guaratinguetá - Lorena.

\section{2 - Clima}

A bacia hidrográfica do Paraíba do Sul apresenta clima Subtropical quente, de acordo com Köppen, a região do Vale do Paraíba é classificada como Cwa, mesotérmico úmido, com verões quentes e invernos amenos e temperatura anual média de $21^{\circ} \mathrm{C}$. Fora da Bacia ou atingindo-a em algumas regiões é encontrado o tipo climático $\mathbf{C f b}$, de clima temperado com inverno menos seco.

As precipitações mais elevadas e com maiores diferenças ocorrem na Serra da Mantiqueira, com médias entre 1.300 a 2.000 mm, e na Serra do Mar, com médias entre 
1.300 a $2.800 \mathrm{~mm}$. A região do Vale do Paraíba, situada entre as duas serras, possui os mais baixos índices de precipitação de toda a bacia, com volumes variando entre $1.200 \mathrm{e}$ $1.300 \mathrm{~mm}$ (SÃO PAULO, 2005). Conti (1998) associa o posicionamento paralelo das duas serras em oposição à direção dos ventos e das correntes de circulação atmosférica ao comportamento das precipitações nas regiões de maior altitude.

Os meses que ocorrem as maiores médias pluviométricas são dezembro e janeiro, com volume médio acumulado entre 200 e 250 mm/mês, já o intervalo de maio a agosto corresponde ao período mais seco, com precipitações inferiores a $50 \mathrm{~mm} / \mathrm{mês}$ (MARENGO e ALVES, 2005). A Dinâmica Climática do Vale do Paraíba não sofre grandes variações devido à presença, na maior parte do ano, da massa Tropical Atlântica (CONTI, 1975). Ele ressalta que a massa Tropical Continental tem uma freqüência menor, num período de baixos índices pluviométricos.

\section{3 - Geologia}

No município de Jacareí ocorrem duas importantes unidades geológicas: a Bacia Sedimentar de Taubaté, de idade cenozóica e o embasamento cristalino pré-cambriano.

A Bacia de Taubaté faz parte do Rift Continental do Sudeste do Brasil (RCSB), que compreende um conjunto de cinco principais bacias de idade cenozóica: Curitiba, São Paulo, Taubaté, Resende e Volta Redonda, dispostas em uma depressão alongada segundo ENE, paralela à costa sudeste brasileira (RICCOMINI, 1989). Presente entre as bacias de São Paulo e Rezende, na parte central do RCSB, contento forma alongada devido a descontinuidades antigas de direção geral ENE do embasamento associada à tectônica distensiva de idade Paleógena (FERNANDES, 1993). A bacia se encontra sobre rochas ígneas e metamórficas do Cinturão de Dobramentos Ribeira, datadas desde o Paleoproterozoico até o Neoproterozoico (HASUI e PONÇANO, 1978). O substrato da Bacia de Taubaté é representado, em sua maior parte, pelo Complexo Embu, constituído por migmatitos com intercalações de metassedimentos referidos ao Complexo Pilar, além de corpos metabásicos (FERNANDES, 1993). Os sedimentos que compõe a Bacia de Taubaté são de origem continental e, de acordo com Riccomini (1989), seu preenchimento pode ser dividido em duas fases: a primeira, sin-tectônica ao rifte, com a deposição dos sedimentos do Grupo Taubaté, composto pelas formações Resende, Tremembé e São Paulo e a segunda, posterior à tectônica diastrófica, com a deposição da Formação Pindamonhangaba e depósitos aluviais e coluviais.

O embasamento cristalino é composto especialmente por gnaisses bandados e 
migmatitos diversos, com ocorrência de bolsões pegmatíticos, associados a zonas de cisalhamento, que foram enfeixados no Complexo Paraíba do Sul, de idade proterozóica inferior (IPT, 1990). As feições que mais chamam a atenção dentre as estruturas nesses litotipos está relacionada a uma foliação milonítica de direção ENE-WSW, com mergulhos em geral de alto ângulo, em sua maioria direcionando a noroeste, e ocorrem ainda granitóides sin-tectônicos pertencentes à Suíte Jambeiro, cuja origem foi interpretada como anatexítica, associada ao Ciclo Brasiliano (1.000 - 600 Ma.) (BISTRICHI et al., 1996).

\section{4 - Geomorfologia}

A bacia hidrográfica do Paraíba do Sul integra duas unidades geomorfológicas do Estado de São Paulo: o Planalto Atlântico e a Província Costeira. A área de estudo está inserida na zona do Médio Vale do Paraíba do Sul, no Planalto Atlântico.

Depressão de origem tectônica, o Planalto Atlântico compreende a faixa entre a Serra da Mantiqueira ao Norte e a Serra do Mar a Sudeste, com altitudes que vão até 2.500 e $800 \mathrm{~m}$, respectivamente. No interior do Vale formado pelas duas serras, a geomorfologia é suave, com altitudes entre 560 e 650m (COLUMBUS et al., 1980). Por ocorrer em faixa de orogênica antiga, o Planalto Atlântico comumente é subdividido em diversas unidades geomorfológicas, tendo em vista a particularidade das suas características geotectônica, litológicas e estruturais (ROSS e MOROZ, 2011).

Almeida (1964) elaborou uma proposta de divisão geomorfológica do Estado de São Paulo em províncias, zonas e subzonas, tendo em vista as variadas características geotectônicas, litológicas e estruturais, desenvolvidas após diversos ciclos erosivos pré e pós-cretácicos.

A província do Planalto Atlântico é formada essencialmente por rochas metamórficas e eruptivas e estruturas de idade pré-siluriana, e possui uma seqüência de planaltos profundos com diferentes ciclos de erosão (IPT, 1982). O Planalto Atlântico possui diversas subdivisões, o município de Jacareí está localizado na zona geomorfológica Médio Vale do Paraíba que se subdivide nas subzonas: Morros Cristalinos e Bacia de Taubaté.

Os Morros Cristalinos são constituídos por rochas metamórficas do Grupo Açungui, que formam um conjunto de morros alongados, conhecidos como "mares de morros". De acordo com Ab' Sáber (2000) a forma arredondada desse relevo se dá pelo processo fisiográfico de "mamelonização", um sistema de evolução rápida da paisagem quando há ausência de mudanças climáticas extremas, que provavelmente se estabilizou logo após o 
surgimento da floresta tropical.

A Bacia de Taubaté, formada predominantemente por rochas granito-gnáissicomigmatíticas e ortoderivadas, apresenta formas alongadas e se encontram encravadas em rochas mais antigas devido a falhas subverticais, que provocam o abatimento dessas áreas. Com sedimentos de origem continental, sua formação se iniciou no Terciário e ainda continua se desenvolvendo nos dias atuais, devido à ação dos rios principais e seus tributários e a processos erosivos das serras que se limitam com o Vale do Paraíba (BISTRICHI et al., 1996).

\section{5 - Solos}

De acordo com Oliveira (1999), os solos do Vale do Paraíba apresentam cinco importantes classes: Latossolos Vermelhos (LV) e Latossolos Vermelho-Amarelos (LVA); Argissolos Vermelho-Amarelos (PVA); Cambissolos Háplicos (CX) e Cambissolos Húmicos $(\mathrm{CH})$; Gleissolos Melânicos (GM) e Espodossolos (E). As duas principais classes de solo presente no município de Jacareí são:

a) Latossolos Vermelhos (LV) e Latossolos Vermelhos - Amarelos (LVA), que ocorrem na maioria dos municípios localizados no Vale do Paraíba com relevos que vão de suavemente ondulado a ondulado e altitudes entre 500 e 1000m, principalmente nas áreas mais baixas das Serras da Mantiqueira e do Mar;

b) Gleissolos Melânicos (GM), que compreende a parte da Bacia Sedimentar de Taubaté, do município de Jacareí a Cachoeira Paulista, estendendo-se pela parte mais recente do Vale do Paraíba do Sul. Com relevo de plano até suavemente ondulado e altitudes entre 400 e 500m, apresenta baixo índice de infiltração e elevado encharcamento das áreas de várzea durante os períodos de chuvas.

\section{6 - Vegetação}

Até o início do século XIX, a vegetação do Vale do Paraíba não havia sofrido grandes alterações na sua paisagem natural. As áreas litorâneas e as serras eram cobertas pela densa vegetação da Mata Atlântica e suas árvores altas de copa fechada e galhos cobertos de outras plantas, contrastando com a vegetação encontrada ao longo do Vale, que apresentava uma fitofisionomia mais aberta de campos, com árvores baixas e cascas espessas (SPIX e MARTIUS, 1981). Encontravam-se ainda, em áreas menos expressivas, a 
presença do bioma Cerrado, que ocorriam mais ao leste do Vale e alguns poucos fragmentos de Floresta Estacional Semidecidual.

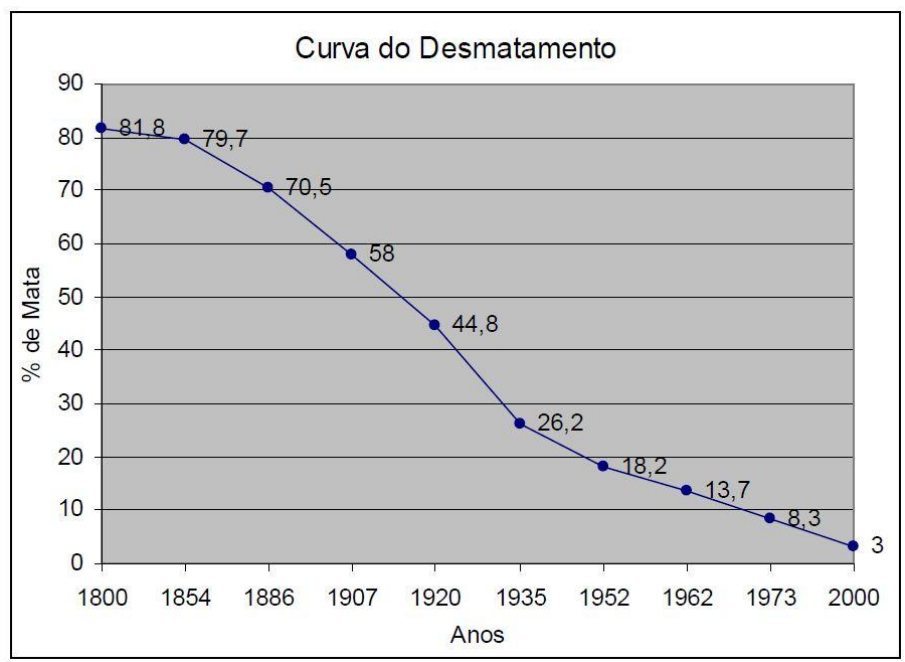

Figura 3. 4 - Curva de regressão da cobertura florestal do Estado de São Paulo (VICTOR et al., 2005).

Atualmente a vegetação apresenta uma pequena quantidade de fragmentos de floresta desconectados entre si por vastos campos abertos que antes serviram de áreas de cultivo, e hoje são utilizados como áreas de pastagem. A fisionomia rala dos pastos com capões de mato estende-se ao longo do Vale entre a Serra do Mar até as baixadas da Serra da Mantiqueira (FREITAS JUNIOR e MARSON, 2007). Os resquícios de mata atlântica que ainda resistem são encontrados na sua grande maioria nas áreas serranas.

\section{7 - Erosões no Estado de São Paulo}

Os estudos relacionados às erosões são de extrema importância para a compreensão dos mecanismos associados aos processos erosivos. Nesse sentido, trabalhos como o desenvolvido pelo projeto "Orientações para o combate à erosão no Estado de São Paulo", em convênio firmado entre o Departamento de Águas e Energia Elétrica - DAEE e o Instituto de Pesquisas Tecnológicas - IPT, onde foram realizados diagnóstico e prognóstico de erosões configuram-se como de extrema relevância no presente contexto (IPT, 1997). Um dos produtos obtidos no final do projeto, e de grande relevância, foi mapa de suscetibilidade a erosões do Estado de São Paulo (Figura 2.4). 


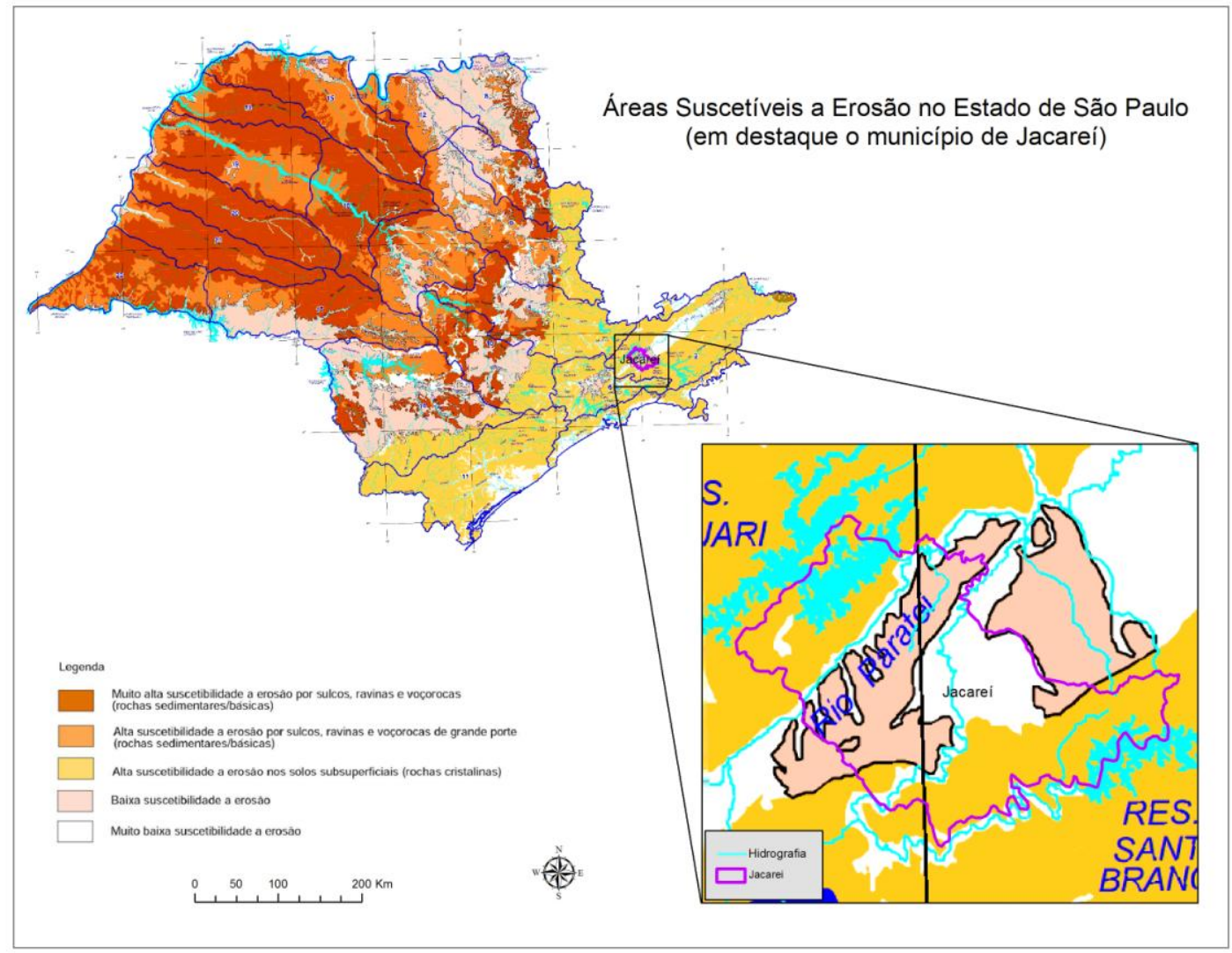

Figura 3. 5 - Mapa de suscetibilidade a erosões no Estado de São Paulo (IPT, 1997).

Das cinco classes apresentadas no mapa de suscetibilidade a erosões no Estado de São Paulo (Figura 2.4), três delas ocorrem no município de Jacareí: alta suscetibilidade a erosão nos solos subsuperficiais; baixa suscetibilidade a erosão; e muito baixa suscetibilidade a erosão. A área de pesquisa delimitada dentro do município se encontra numa região de muito baixa suscetibilidade a erosão. 


\section{4 - METODOLOGIA}

O presente trabalho se baseia na construção de MDS e MDT, utilizando técnicas de restituição aerofotogramétrica e mapas de área de contribuição pré e pós-urbano, para análise do desenvolvimento de voçorocas em áreas urbanizadas. Os modelos digitais foram elaborados nos dois principais módulos do sistema fotogramétrico Inpho, o MATCH-T DSM e o DTMaster, com crescente utilização pela comunidade científica (LEMAIRE, 2008; HÖHLE, 2009; COSTANTINO e ANGELINI, 2011; GÜLCH, 2009).

As fotografias digitais e ortofotos utilizadas na pesquisa fazem parte do Levantamento Aerofotogramétrico do Estado de São Paulo, elaborado pela Empresa Paulista de Planejamento Metropolitano (EMPLASA), nos anos de 2010/2011, e foram cedidos através do Contrato de Licença e Uso - CLU n.ํ 024/15. As fotografias aéreas possuem resolução espacial de 0,45 metros em média e foram capturadas nos períodos mais secos de inverno e as câmeras utilizadas foram as Ultracam, modelo X e XP. As fotografias têm superposição lateral de $60 \%$ e $30 \%$ entre as faixas de vôo e formato digital com composição de cores RGB (red, green and blue). Para entrada no programa de fotogrametria, foi necessário também o arquivo de metadados ( ${ }^{*}$.sup), contendo dados da aerotriangulação referente à cada fotografia. As ortofotos digitais com resolução de 1 metro foram produtos deste aerolevantamento da EMPLASA, elaboradas a partir de um conjunto de 40 fotografias aéreas.

Com base nas ortofotos foram digitalizados vetores de linhas e de pontos representando as voçorocas, áreas com edificações e rede hidrográfica. Após a digitalização, os vetores foram submetidos à correção topológica a fim de eliminar erros nas linhas, pontos e polígonos como: sobreposição, ausência de conectividade, intersecção, entre outros.

Chamou-se de período pré-urbano o modelo representado pela topografia, ou Modelo Digital de Terreno (MDT), em que apenas os dados relativos à topografia do relevo são representados. Já o período chamado de pós-urbano foi representado pelo Modelo Digital de Superfície (MDS) em que, a superfície física do terreno e elementos ou estruturas que se encontram acima dele, como vegetações, edificações são representados. As mudanças nos fluxos superficiais na formação de voçorocas podem ser evidenciadas pela diferença entre as áreas de contribuição do MDT e do MDS. 
A Figura 4.1 apresenta um fluxograma com as etapas metodológicas adotadas. A construção e edição dos modelos digitais foram realizadas no Inpho e a elaboração dos mapas de área de contribuição no ArcGis, através do algoritmo Taudem.

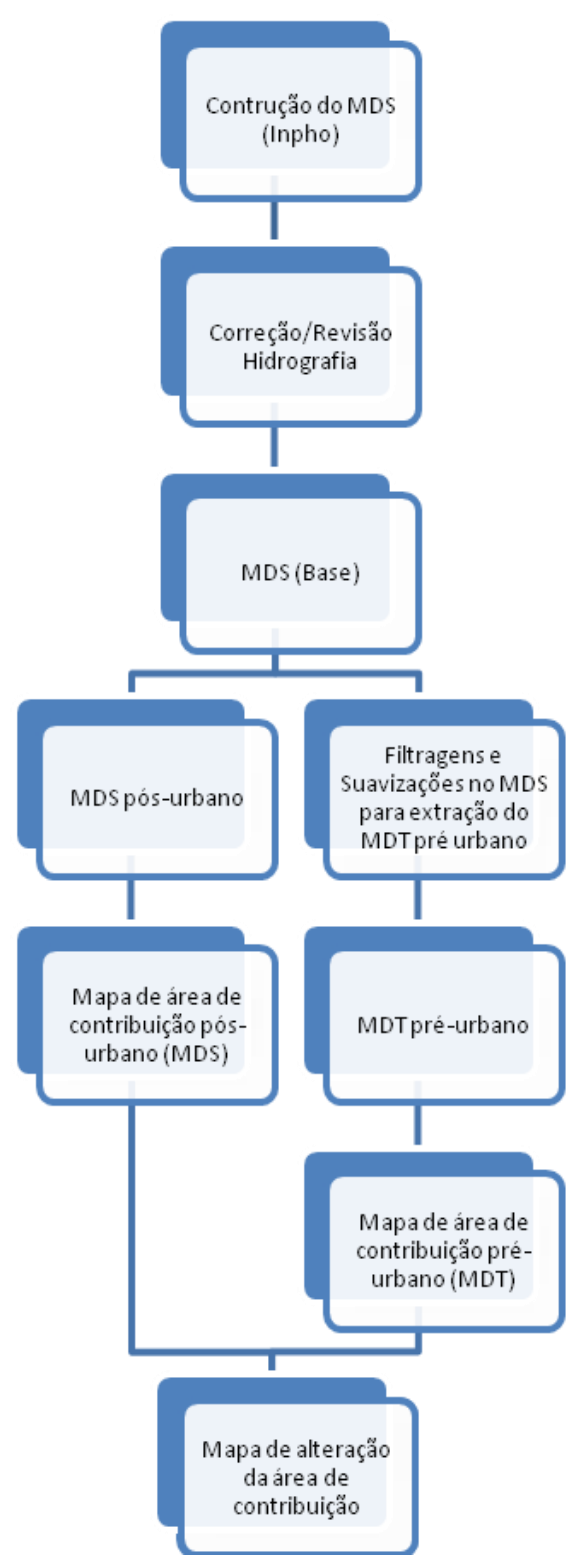

Figura 4. 1 - Fluxograma com as etapas realizadas durante a aplicação da metodologia. 


\section{1 - Elaboração do MDS}

As fotografias aéreas digitais de alta resolução e os metadados com as referências espaciais de cada fotografia foram utilizados como dados de entrada para a elaboração do MDS no módulo MATCH-T DSM, que permite a extração de modelos digitais confiáveis e precisos mesmo em áreas urbanos e ou com vegetação densa, que antes só era possível com o uso de tecnologia LIDAR. No núcleo de gerenciamento de projetos do INPHO (ApplicationsMaster), foram inseridos dados como: identificação e parâmetros da câmera utilizada para aquisição das fotografias, como as distorções e calibrações; dados do sistema inercial (GNSS/IMU); identificação de cada fotografia e definição da sua ordem de acordo com o plano de vôo (strips).

A relação entre as coordenadas da imagem e da câmera, além das informações fiduciais das fotografias estão associadas às orientações interior e exterior, que foram realizadas de forma automática pelo próprio programa, através do processamento de informações contidas no arquivo de metadados. Tal procedimento evita que possíveis erros possam impedir a geração do MDS ou mesmo desfigurá-lo. A configuração correta de todos os parâmetros do projeto é de extrema importância tanto para que a geração do modelo quanto para a edição das nuvens de pontos com visão tridimensional dos pares de fotografias.

Alguns parâmetros foram configurados diretamente no MATCH-T DSM, como dados relacionados à topografia da área a ser modelada e também do tipo de modelo digital a ser gerado. Esses ajustes têm como objetivo melhorar a qualidade do modelo. A tabela I destaca alguns parâmetros adotados na geração automática do modelo, configurados especificamente para o MDS pretendido no presente trabalho.

Tabela I - Configuração dos parâmetros do MATCH-T DSM.

$\begin{array}{cc}\text { Parâmetro } & \text { Configuração Definida } \\ \text { Region Type } & \text { MDS } \\ \text { Grid (minimun size) } & 5 \mathrm{~m} \\ \text { Block } & \text { Complete } \\ \text { Generation type: } & \text { Digital Surface Model } \\ \text { Terrain Type } & \text { Undulating } \\ \text { Smoothing } & \text { Medium } \\ \text { Feature density } & \text { Medium } \\ \text { Point cloud density } & 3 \text { pixel } \\ \text { Parallax threshold } & 14 \text { pixel } \\ \text { Optimize } & \text { Precision } \\ \text { Continue processing } & \text { Habilitada } \\ \text { Strip constraint } & \text { Habilitada }\end{array}$




\section{2 - Correção e revisão da hidrografia}

O MDS extraído apresentou alguns erros na rede de drenagem que poderiam interferir nos resultados dos mapas de área de contribuição. As superfícies de lagos foram representadas com diferentes cotas altimétricas, e alguns cursos de drenagens tiveram seu caminho modificado por influência da altimetria de vegetações. A correção dessas inconsistências foi realizada no DTMaster, através de re-interpolações na nuvem de pontos (Figura 4.2), com o apoio de linhas digitalizadas ao nível do solo.
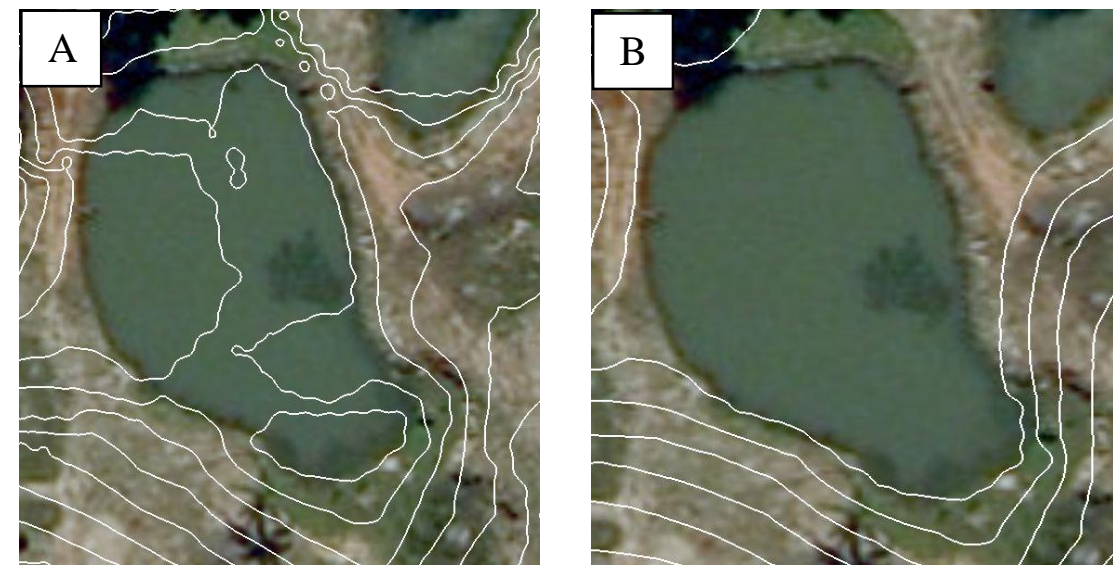

Figura 4. 2 - Inconsistências no MDS antes (A) e depois da correção (B)

\section{3 - Elaboração do MDT}

A elaboração do MDT (cenário pré-urbanização) foi obtida através de filtragens e suavizações do MDS, que visaram modificar a nuvem de pontos dos elementos urbanos para uma representação da superfície do solo. As edições do MDS foram realizadas no módulo DTMaster utilizando visualização tridimensional do terreno a partir dos pares fotogramétricos e auxílio de óculos 3D. A visualização estereoscópica foi possível com o uso da técnica denominada anaglifo, que utiliza óculos que funcionam como filtros e não necessita de uma estação de visualização 3D profissional, com monitores e placas de vídeos especiais. As filtragens de objetos (vegetações, edificações, postes e torres) foram realizadas diretamente na nuvem de pontos que passou a representar apenas a superfície do relevo e, não mais os telhados e copas das árvores. Complementarmente, linhas paralelas às ruas no nível do solo foram digitalizadas para que fossem utilizadas como 
referência no momento da interpolação dos pontos que seriam "rebaixados" (Figura 4.3). A interpolação seguindo este método possibilita que os elementos urbanos sejam filtrados de forma que as cotas altimétricas obedeçam à topografia das ruas, mesmo quando há variações em suas extremidades. Esta filtragem foi realizada de quadra em quadra, de modo que todos os pontos alterados fossem realocados no nível altimétrico pretendido, o que fez dela, a etapa que mais demandou tempo ao longo do trabalho.

A ferramenta de exibição em perfil do DTMaster possibilita visualização tridimensional da nuvem de pontos, que pode ser rotacionada em qualquer direção. Cada ponto do modelo digital é exibido no cubo do perfil de acordo com a sua altimetria e as alterações realizadas são exibidas simultaneamente à edição (Figura 4.4).
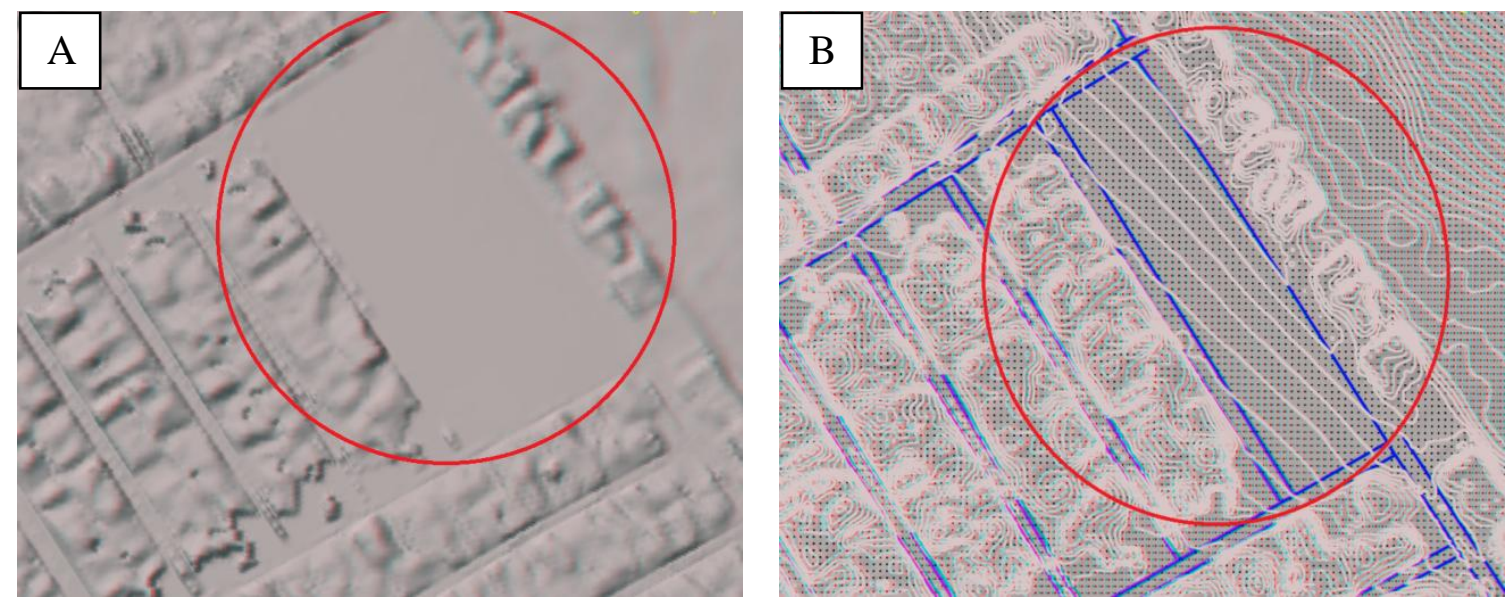

Figura 4. 3 - Relevo sombreado com parte editada (A) e relevo sombreado com parte editada, linhas de apoio (azul) e curvas de nível (cinza) (B).
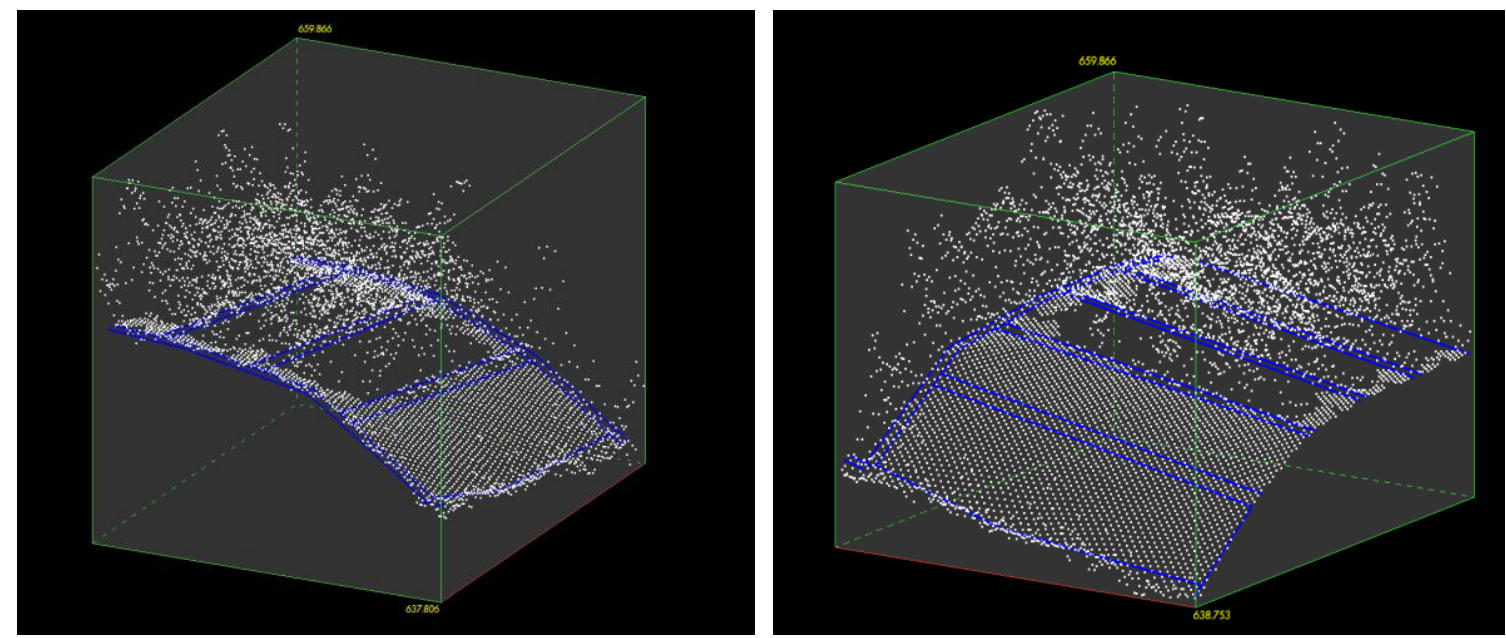

Figura 4. 4 - Perfis topográficos da nuvem de pontos com parte filtrada.

A ferramenta de exibição em perfil do DTMaster possibilita visualização tridimensional da nuvem de pontos, que pode ser rotacionada em qualquer direção. Cada 
ponto do modelo digital é exibido no cubo do perfil de acordo com a sua altimetria e as alterações realizadas são exibidas simultaneamente à edição.

As voçorocas existentes na área de estudo foram suavizadas para que não influenciassem no fluxo pré-urbano, direcionando-o para pontos específicos. As características topográficas e localização destas feições indicam que seu desenvolvimento possui forte relação com o escoamento superficial concentrado. A Figura 4.5 representa uma área que não sofria ação de processo erosivo e que após a intensificação do processo de urbanização foi desenvolvida uma voçoroca.

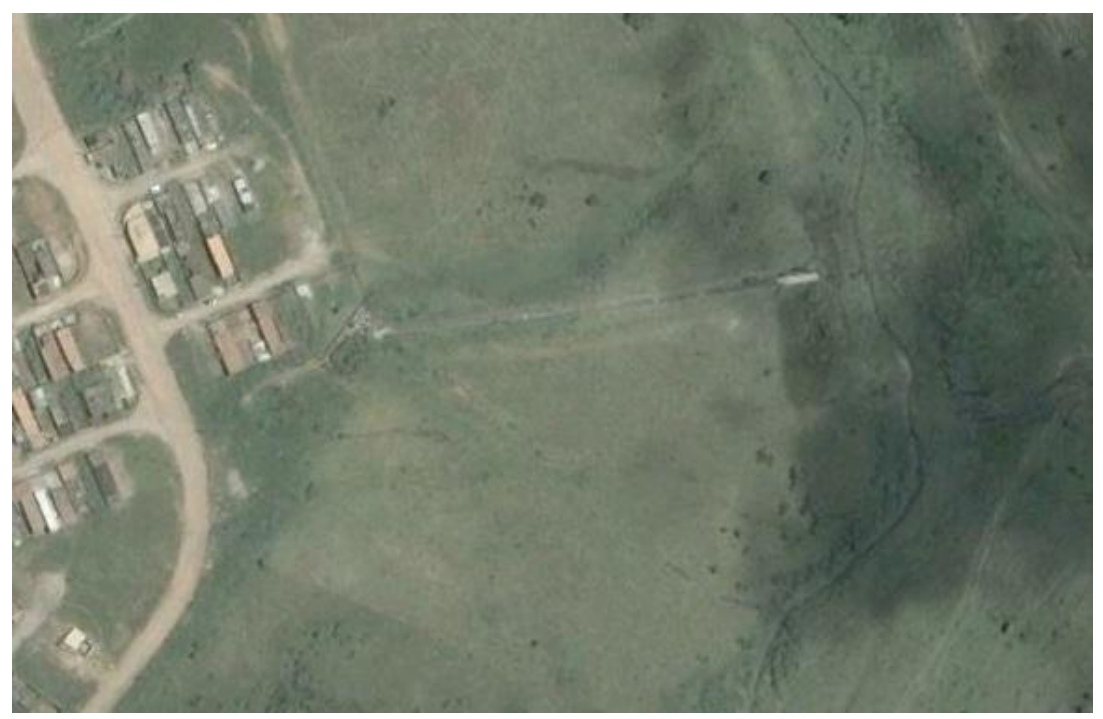

Figura 4. 5 - Imagem do Google Earth de área antes da ocorrência de voçoroca.
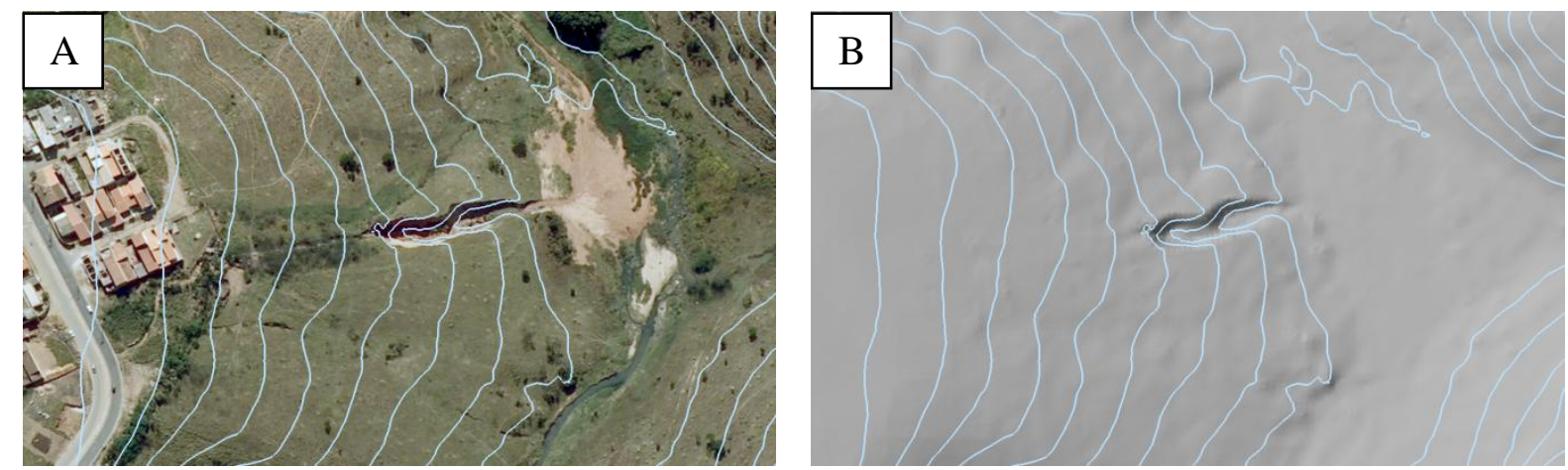

Figura 4. 6 - Ortofoto $(A)$ e relevo sombreado $(B)$ antes da filtragem de voçoroca. 

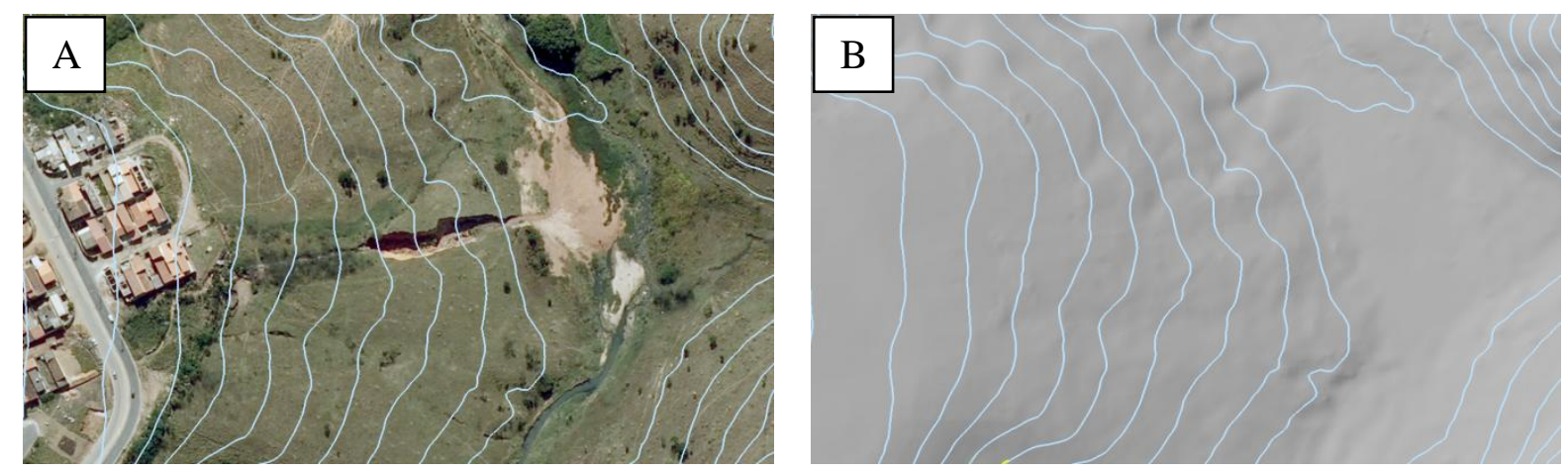

Figura 4. 7 - Ortofoto $(A)$ e relevo sombreado $(B)$ após filtragem de voçoroca.

As áreas com vegetação foram filtradas e suavizadas com o auxílio de linhas de drenagens e linhas paralelas às curvas de nível, digitalizadas de acordo com a visualização em 3D. Essas linhas digitalizadas foram utilizadas como referência durante a interpolação, resultando em curvas de nível corrigidas que passaram a representar apenas a superfície física do terreno e não mais as copas das árvores.
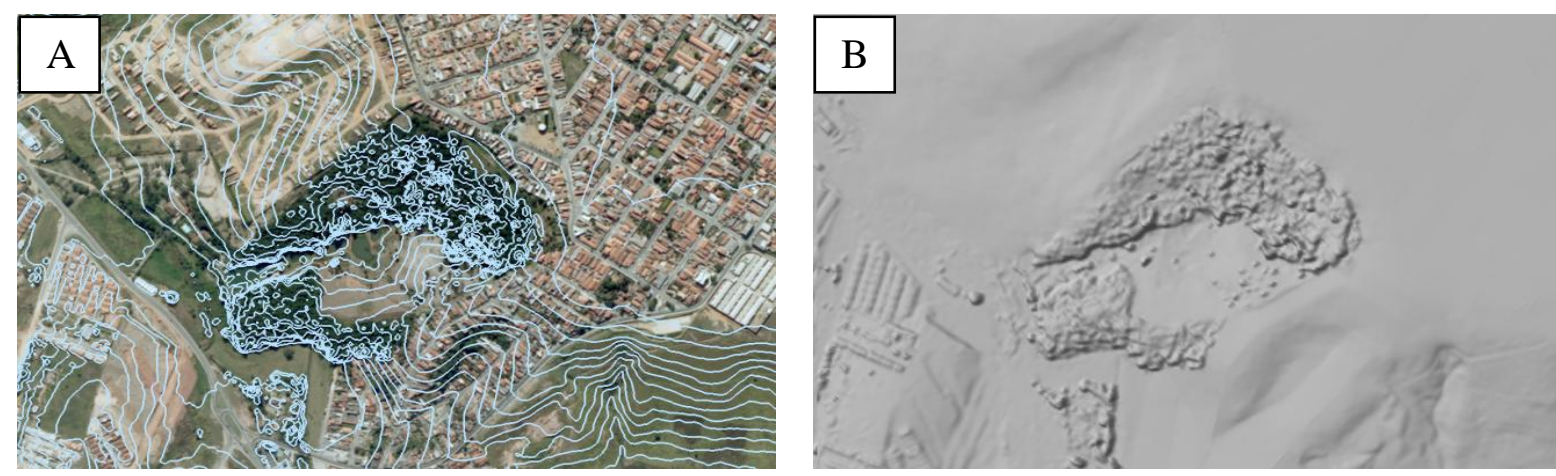

Figura 4. 8 - Ortofoto com as curvas de nível (esquerda) e MDS (direita), antes da edição.
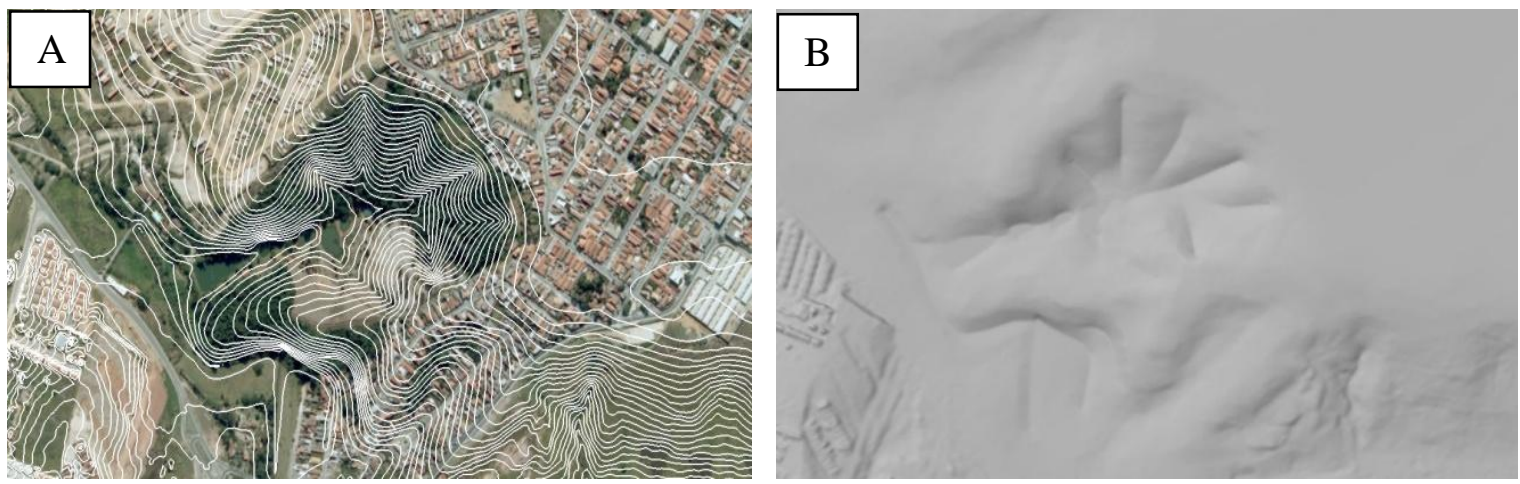

Figura 4. 9 - Ortofoto com as curvas de nível (A) e MDT (B) após filtragem da vegetação. 
As linhas utilizadas como apoio na interpolação de área urbana apresentaram alguns erros residuais como falsos patamares formados pelas bordas das ruas (figura 4.9), esses erros foram corrigidos para que a morfologia fosse representada de forma homogênea.
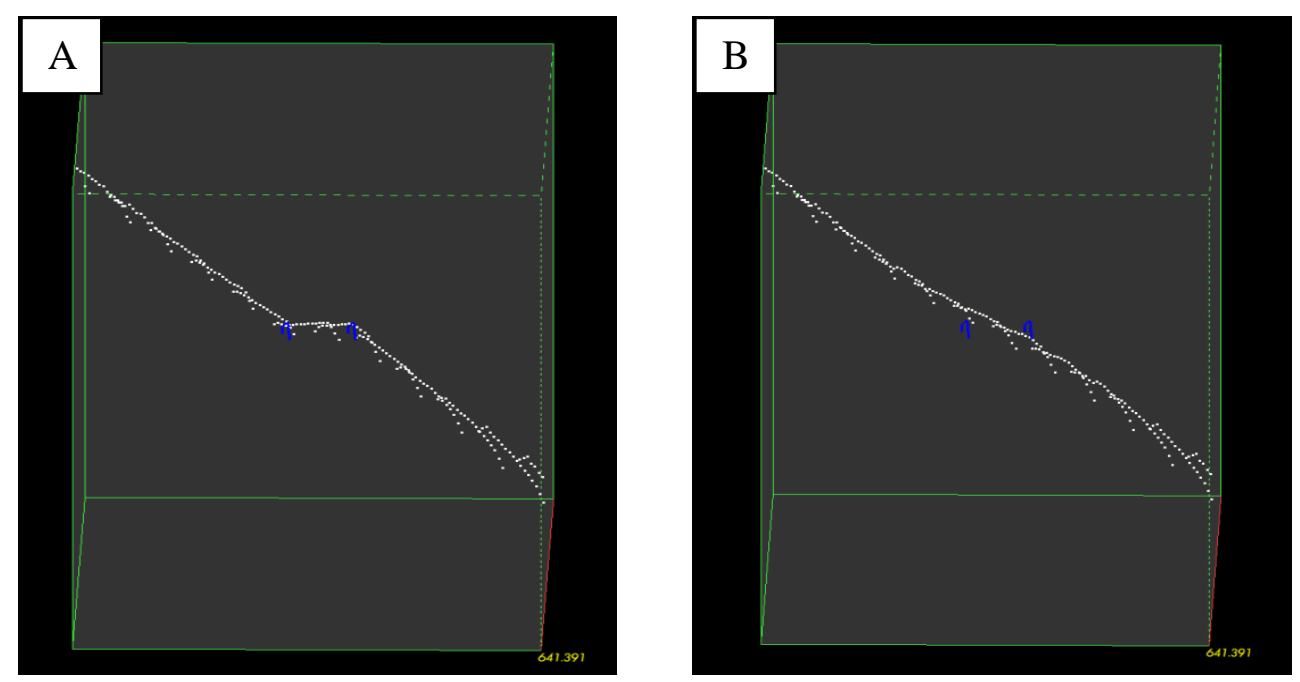

Figura 4. 10 - Perfis topográficos dos erros residuais antes $(A)$ e depois $(B)$ da correção.
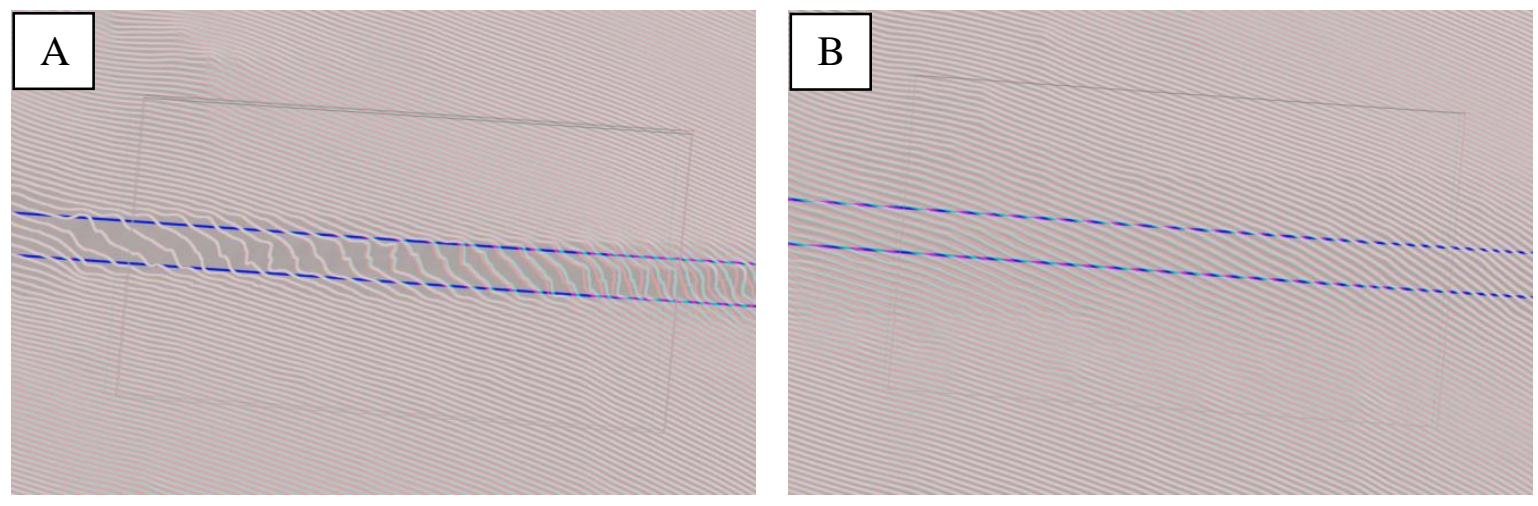

Figura 4. 11 - Erros residuais antes (A) e depois (B) da correção.

\section{4 - Mapas de Área de Contribuição}

A modelagem matemática é bastante utilizada nas análises de dinâmica hídrica tanto em ambientes naturais como em ambientes urbanizados. Os modelos hidrológicos podem ser definidos como representação matemática do fluxo de água e seus constituintes sobre alguma parte da superfície e/ou subsuperfície terrestre (O'LOUGHLIN, 1986). Um dos principais atributos utilizados na modelagem hídrica é a área de contribuição. As metodologias para obtenção desse atributo de terreno são variadas e os métodos que mais 
se destacam são: (a) método D-8, em que o fluxo tem oito possíveis direções, sendo direcionado para célula vizinha de menor cota altimétrica (O'CALLAGHAN e MARK, 1984); (b) o método em que o fluxo é distribuído de forma proporcional à jusante do ponto de análise, conforme a declividade (Quinn et al., 1991); e (c) o método D-Infinito em que o fluxo é distribuído proporcionalmente entre as duas direções com maior desnível (TARBOTON, 1997).

No presente trabalho, os mapas de área de contribuição foram gerados utilizando o método D-Infinito (TARBOTON, 1997). Foram elaborados mapas de área de contribuição para os períodos pré e pós-urbanos. O dado de entrada utilizado para elaboração do produto pós-urbano foi o MDS e para simulação do período pré-urbano foi utilizado o MDT extraído no Inpho. Foram aplicados o log10 nesses mapas de área de contribuição (pré e pós-urbanização), a fim de melhorar a visualização dos resultados obtidos.

De posse dos mapas de área de contribuição pré e pós-urbanização, foi possível elaboração de mapa identificando as mudanças entre os dois períodos. Neste método, o mapa de área de contribuição simulando no período pré-urbano foi subtraído do mapa que representava o período pós-urbano, tendo como resultado um mapa demonstrando os locais onde houve modificação na dinâmica da rede de drenagem. 


\section{5 - RESULTADOS E DISCUSSÕES}

Os resultados obtidos após aplicação da metodologia apresentada estão relacionados principalmente a cinco voçorocas localizadas dentro da área de pesquisa (Figura 5.1). Foram realizadas análise nas áreas que apresentaram maiores modificações na dinâmica hidrológica, como em regiões que não apresentaram voçorocas.

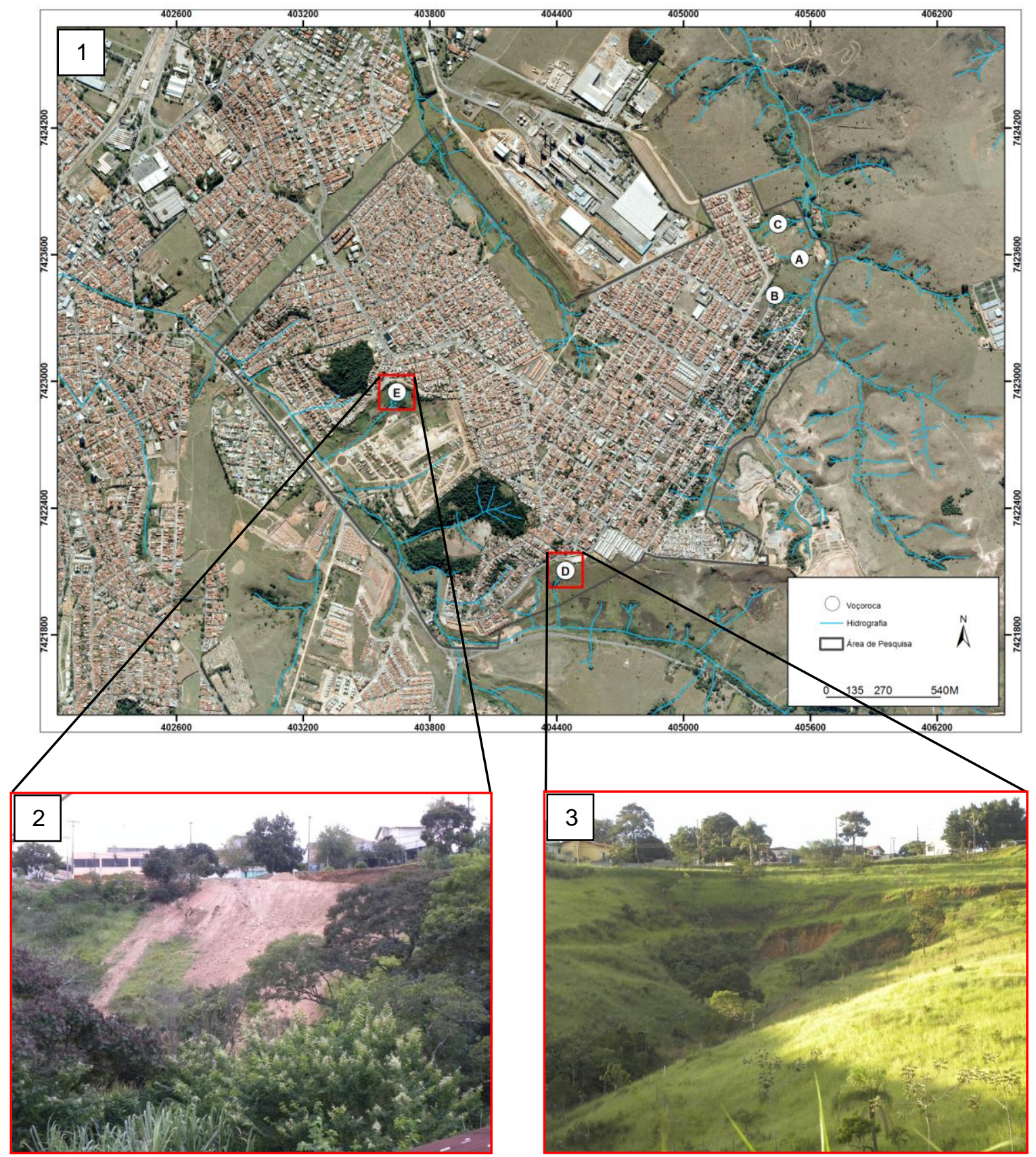

Figura 5. 1 - Ocorrência de voçorocas dentro da área de pesquisa (1). Fotografia de voçoroca em processo de recuperação (2) e fotografia de voçoroca (3). 
O MDS representou bem a nuvem de pontos relativa ao relevo e aos elementos naturais e urbanos que se encontram acima da superfície (Figura 5.2, A). A correção e revisão da hidrografia foram essenciais na construção do MDS, por ter influência direta na qualidade do mapa de área de contribuição. Os elementos urbanos estão visivelmente bem representados e o relevo sombreado dá ênfase nas diferenças de altimetria entre as áreas com edificações e o nível do solo das ruas.

As restituições realizadas no DTMaster possibilitaram a extração de um MDT consistente, representando apenas a topografia do relevo (Figura 5.2, B). A topografia filtrada e suavizada resultou numa área mais homogênea, modificando regiões onde anteriormente continham cotas altimétricas de elementos urbanos. Esse resultado influencia diretamente na acurácia do mapa de área de contribuição. Os dois modelos apresentam mudanças altimétricas evidentes, a altitude máxima do MDT foi de 664 metros, enquanto o MDS foi de 671 metros, uma redução condizente com as cotas altimétricas dos elementos que estavam acima do solo, como as edificações. As diferenças entre os modelos são ainda mais acentuadas quando comparamos a mesma linha de perfil topográfico (perfis $A-B$, Figura 5.2 A e B).

O mapa de área de contribuição pós-urbano apresentou uma concentração de fluxo em direções específicas (Figura 5.3, A). As áreas edificadas no interior das quadras formaram divisores de drenagem direcionando o fluxo para as ruas que funcionaram como canais de drenagem, transportando a água para fora da área projetada. A alteração no terreno devido à urbanização modificou toda a dinâmica do fluxo pós-urbano em relação período pré-urbano.

O mapa de área de contribuição do MDT corresponde às áreas naturais préurbanização, sem a presença das alterações antrópicas (Figura 5.3, B). O escoamento difuso é predominante ao longo do relevo e em direção às drenagens principais, com concentração de fluxo apenas nas principais redes de drenagem. 

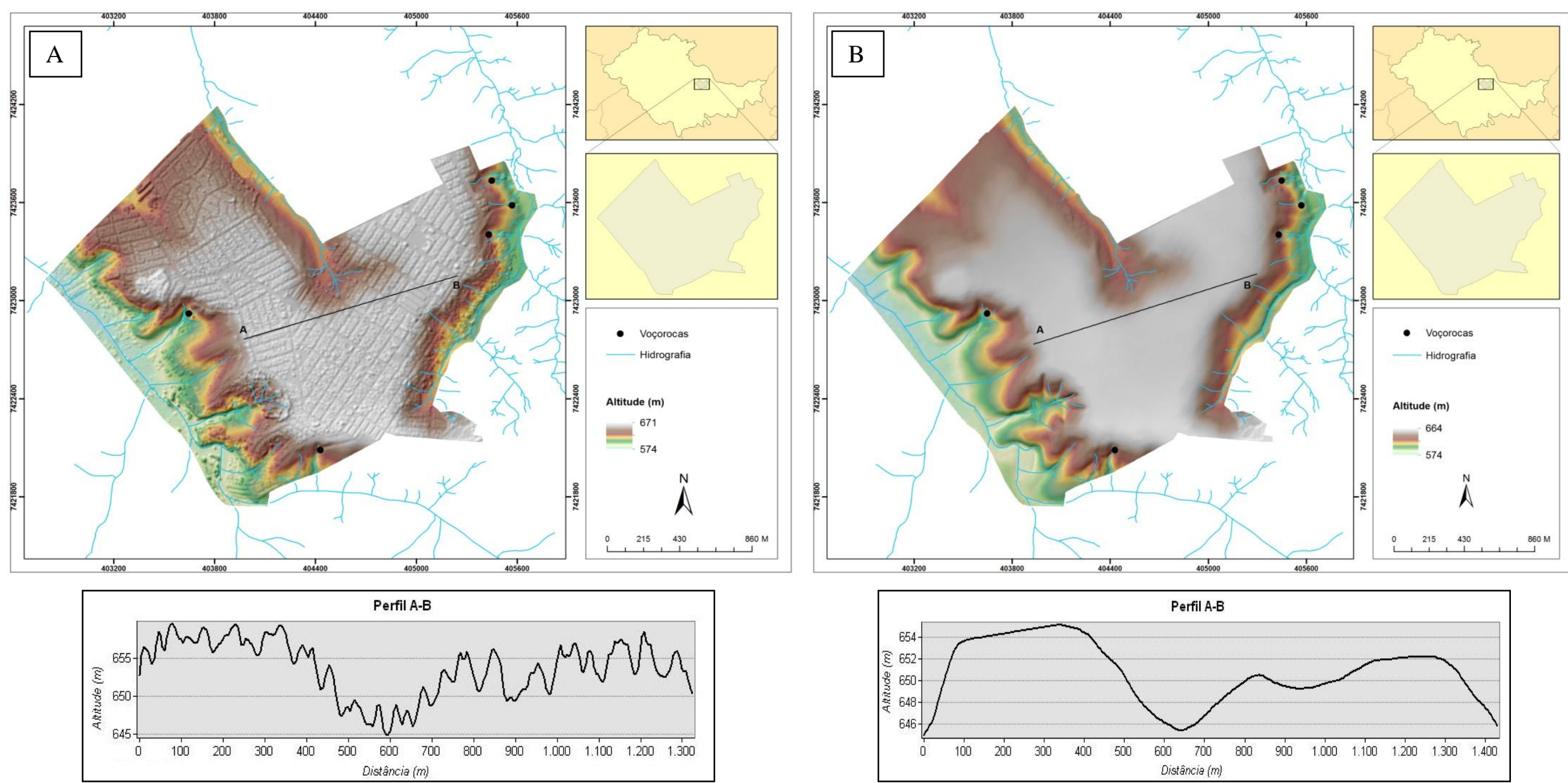

Figura 5. 2 - MDS pós-urbano (A) e MDT pré-urbano (B), (exibição de superfície hipsométrica com relevo sombreado) e respectivos perfis topográficos 

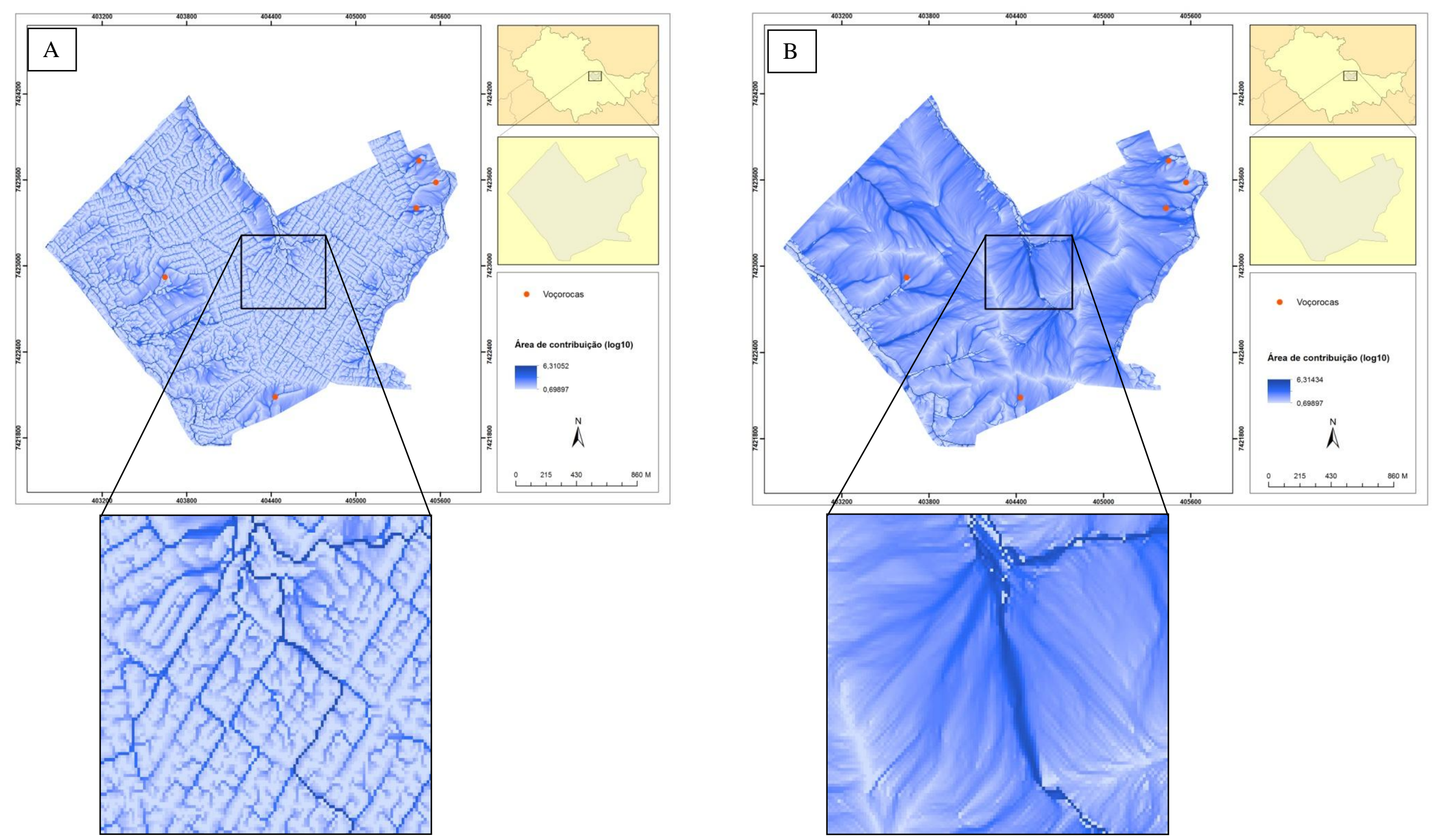

Figura 5. 3 - Mapa de área de contribuição pós-urbano (A) e pré-urbano (B). 
As diferenças entre o MDS e o MDT foram evidenciadas com as representações das Figuras 5.4 e 5.5, obtidas com a utilização da ferramenta de perfil em 3D do DTMaster. O cubo demonstra o comportamento da nuvem de pontos pós e pré-urbanização em relação às linhas de apoio digitalizadas no nível do solo, utilizadas durante a interpolação.
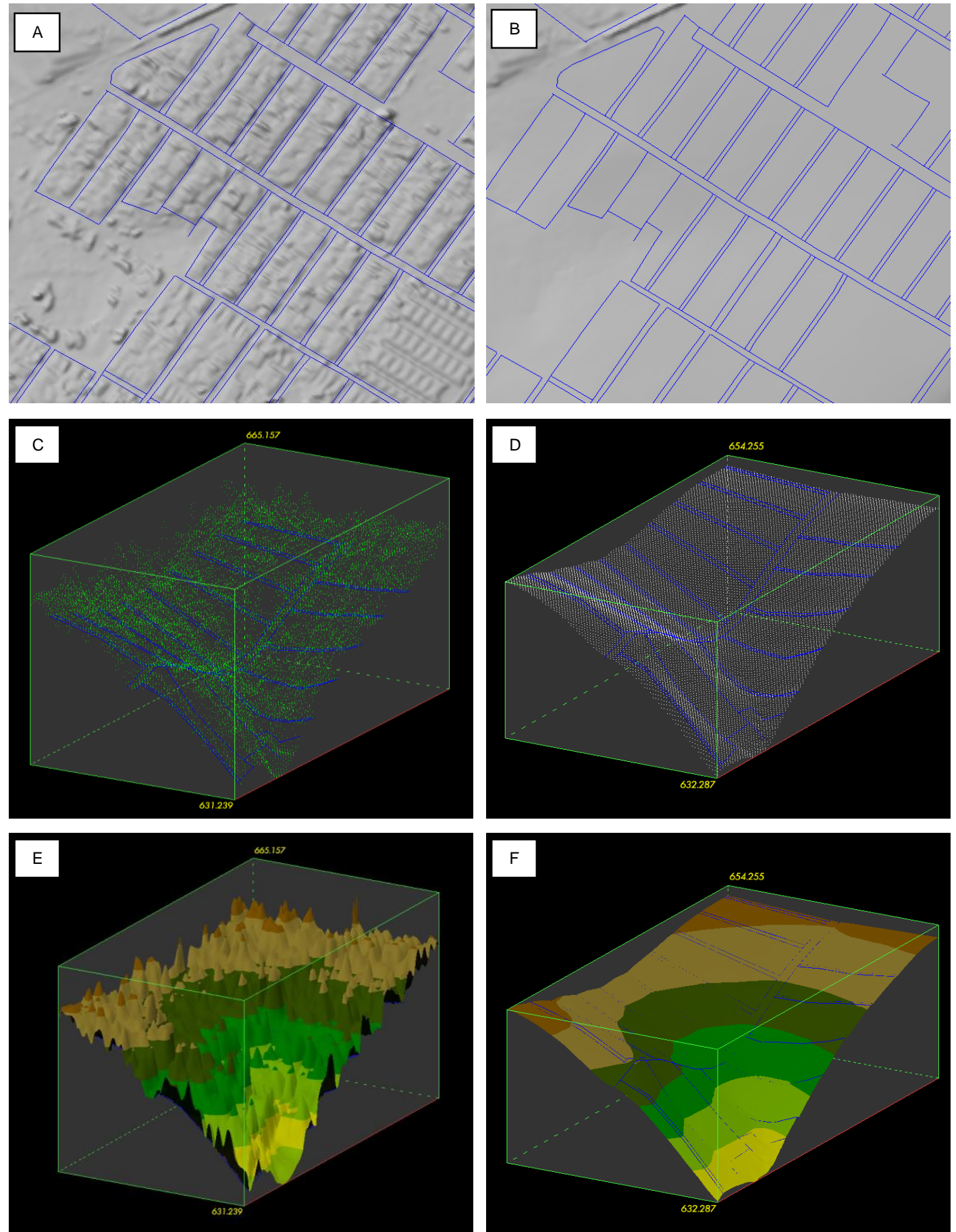

Figura 5. 4 - Relevo sombreado pós e pré-urbano (A-B); exibição do perfil topográfico da nuvem de pontos pós e pré-urbano (C-D); e perfil com exibição hipsométrica e relevo sombreado pós e pré-urbanos (E-F). 
A Figura 5.5 (C, D) destaca as modificações ocorridas nas curvas de nível de uma área com de vegetação densa, em que os pontos representavam as copas das árvores (MDS) e passaram a representar apenas a superfície do relevo (MDT).
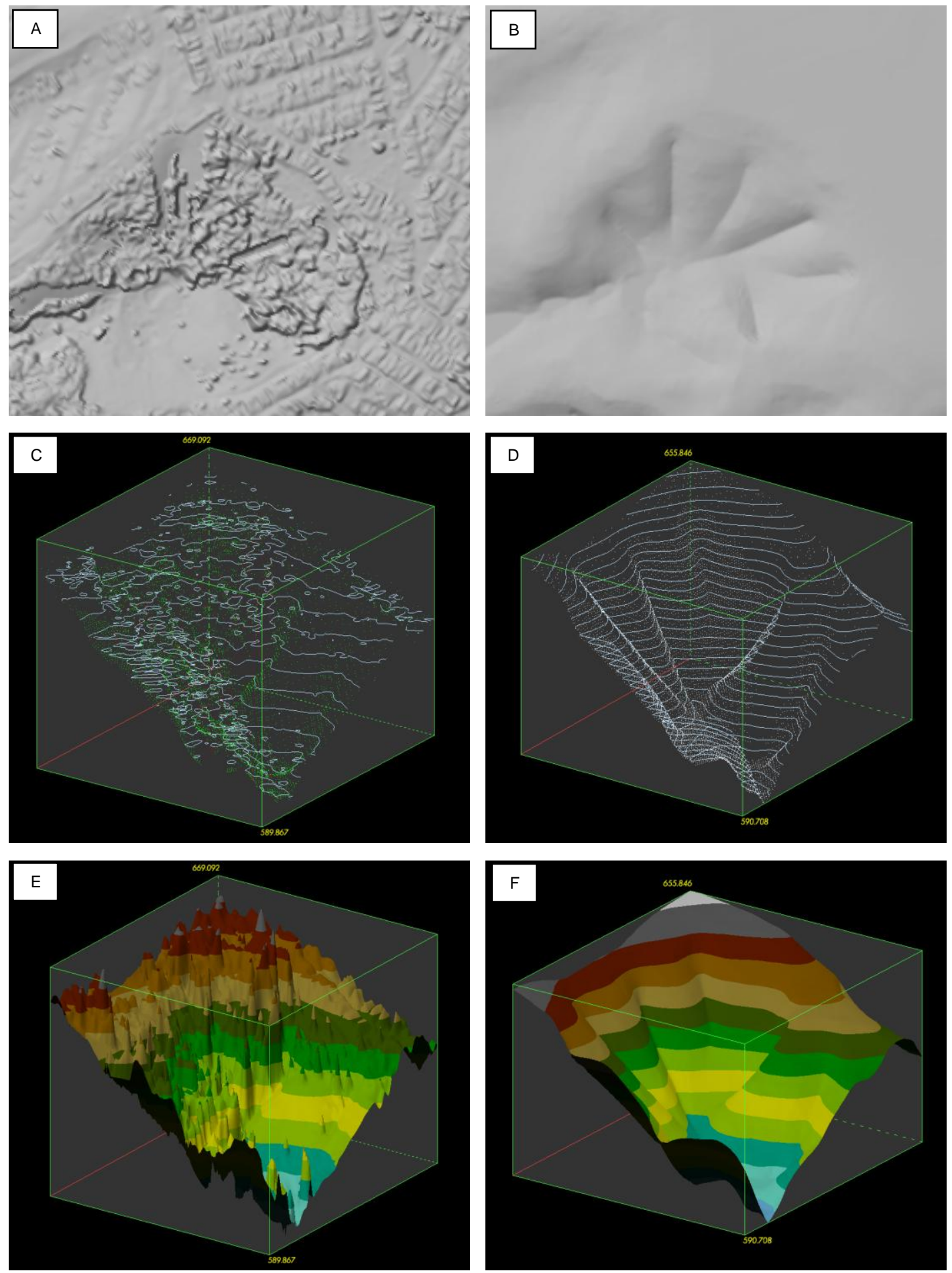

Figura 5. 5 - Relevo sombreado pós e pré-urbano (A-B) de área com vegetação; exibição do perfil topográfico da nuvem de pontos pós e pré-urbano (C-D); e perfil com exibição hipsométrica e relevo sombreado pós e pré-urbanos (E-F). 
A diferença entre os mapas de área de contribuição pré e pós-urbano demonstra uma significativa modificação entre os períodos, onde o fluxo representado em azul escuro se refere ao período pré-urbano e as linhas brancas o pós-urbano (Figura 5.6).

O gráfico da Figura 5.7 apresenta valores de alguns pontos coletados dos mapas de área de contribuição pré e pós-urbano. As áreas com desenvolvimento de voçorocas (demarcadas com um círculo) apresentaram um aumento da área de contribuição pósurbanização em comparação ao cenário pré-urbano. Isso evidência o desenvolvimento de voçorocas a partir da urbanização (Figuras 5.6 e 5.7). Os pontos com elevada perda da área de contribuição de até quatro ordens de grandeza (simbolizados por um quadrado) demonstram uma mudança de fluxo, que passou a ter novas direções antes de chegar nesse ponto.

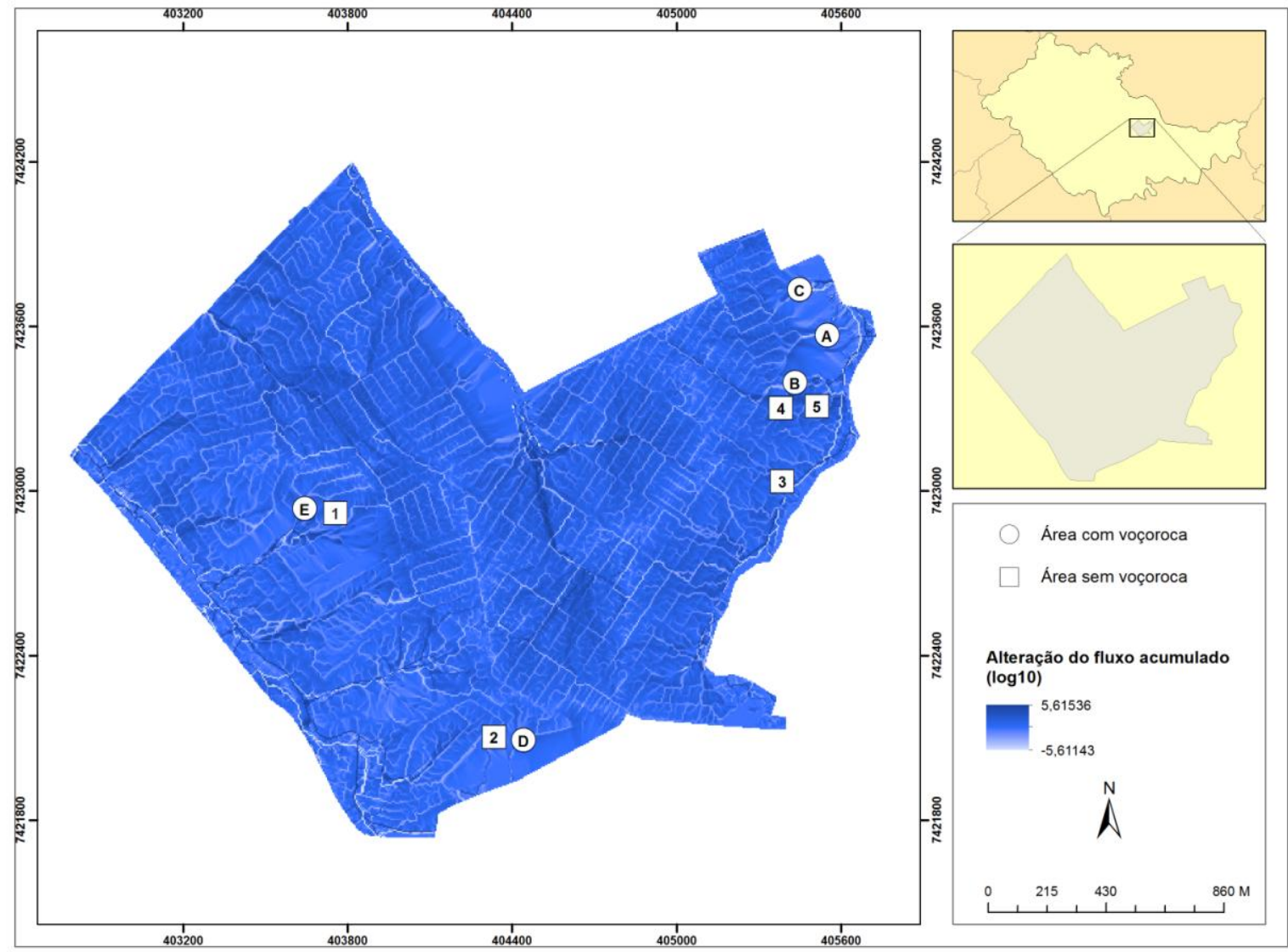

Figura 5. 6- Mapa de alteração da área de contribuição. Os círculos representam áreas que apresentaram aumento de fluxo e desenvolveram voçorocas e os quadrados representam áreas em que o fluxo diminuiu e não desenvolveram voçorocas. 


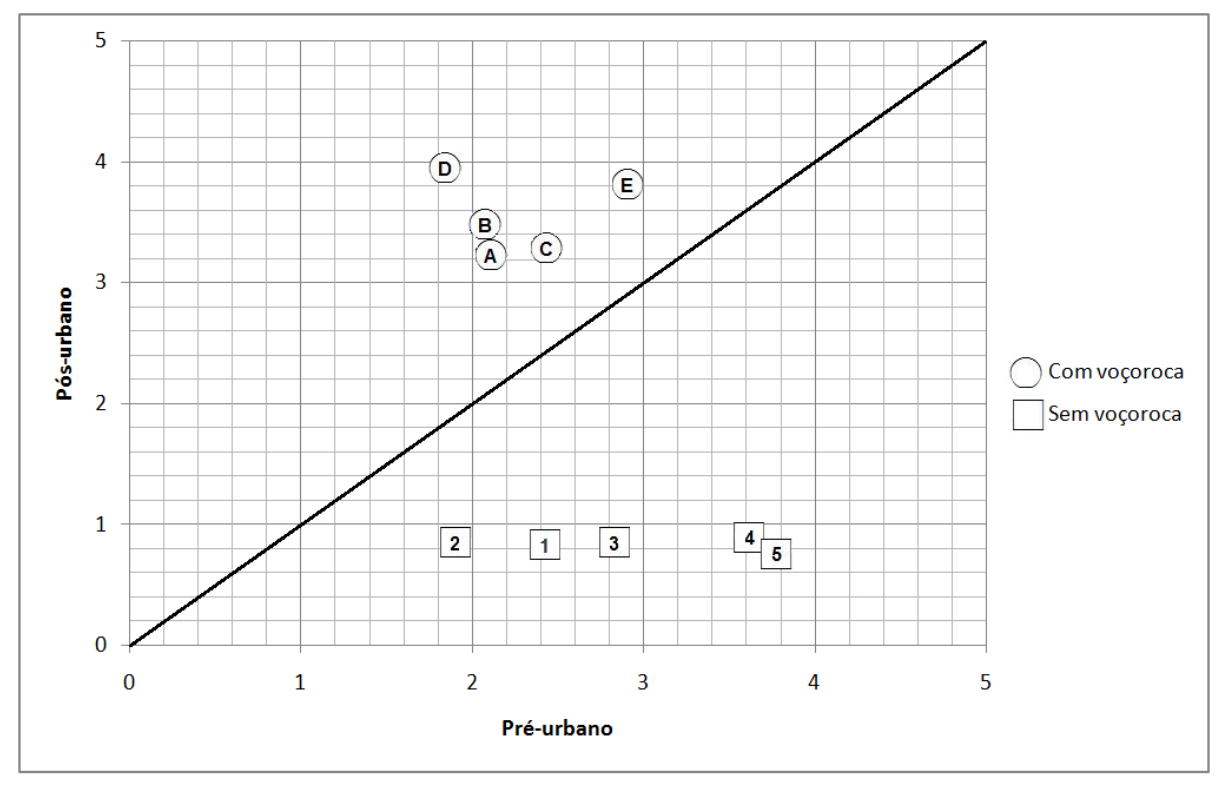

Figura 5. 7 - O gráfico representa os valores de fluxo dos períodos pré e pós-urbano. Os círculos e quadrados do gráfico também estão representados na Figura 5.6.

A área destacada na Figura 5.8 não apresentava de voçoroca nos dados do levantamento aerofotogramétrico utilizados no trabalho (2010/2011), porém, foi verificada uma proeminente voçoroca em foto tirada recentemente do local. Por esse motivo ela foi incluída nas análises do mapa de alteração de área de contribuição da Figura 5.6 e no gráfico da Figura 5.7 (círculo "E"). Esse ponto apresentou aumento de fluxo no período pósurbano similar ao das outras áreas com voçorocas. Foi realizada uma análise multitemporal com imagens coletadas de diversos períodos no Google Earth (Figura 5.9), onde se pôde verificar que o desenvolvimento da voçoroca se deu com a intensificação do processo de urbanização, principalmente devido à impermeabilização do solo causado pela pavimentação das ruas e instalação de meios fios que ocorreu nas ruas próximas. Nota-se que fluxo passou a ser direcionado para pontos específicos na encosta em destaque. 


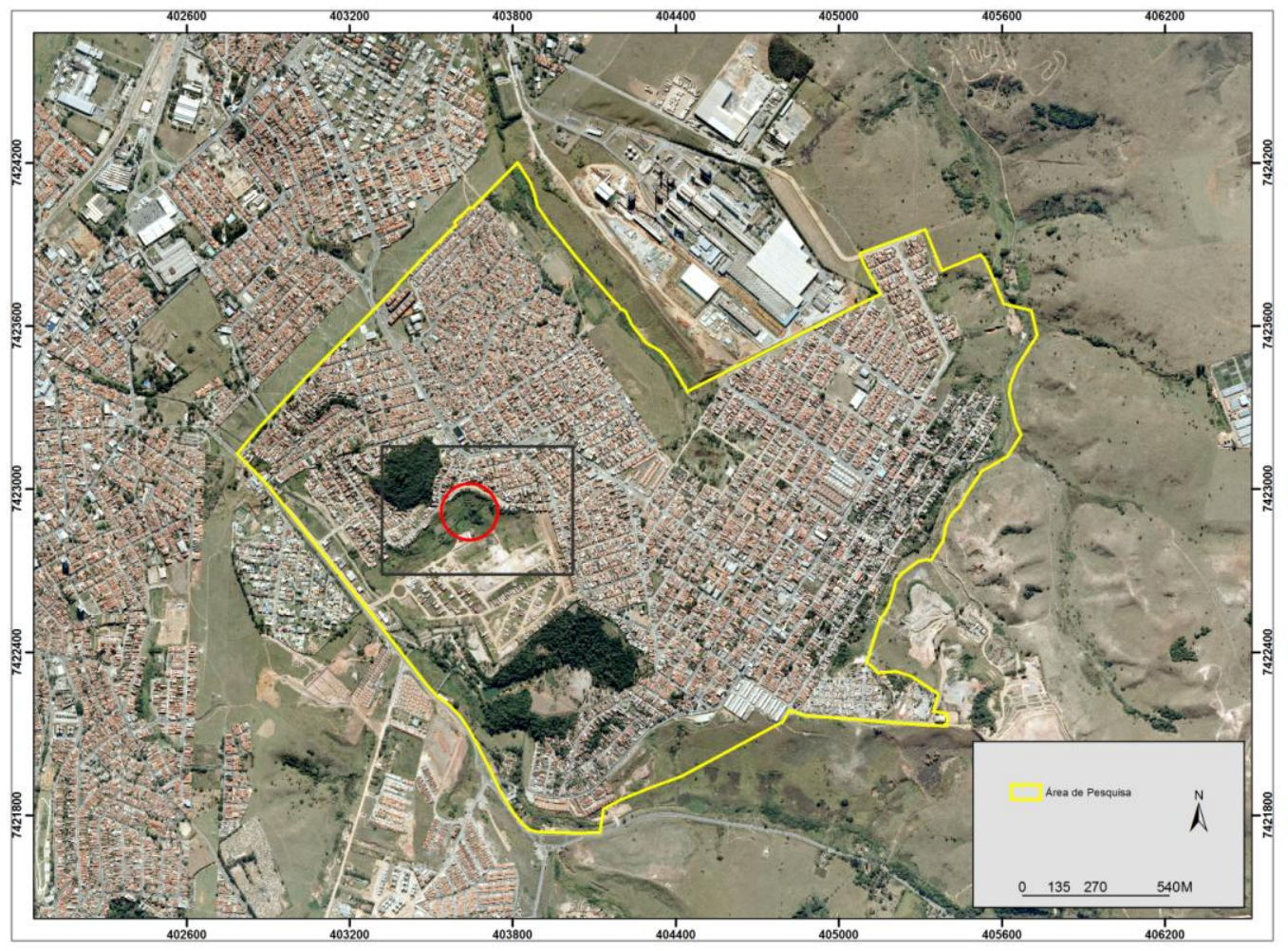

Figura 5. 8 - Localização da área submetida a análise multitemporal.
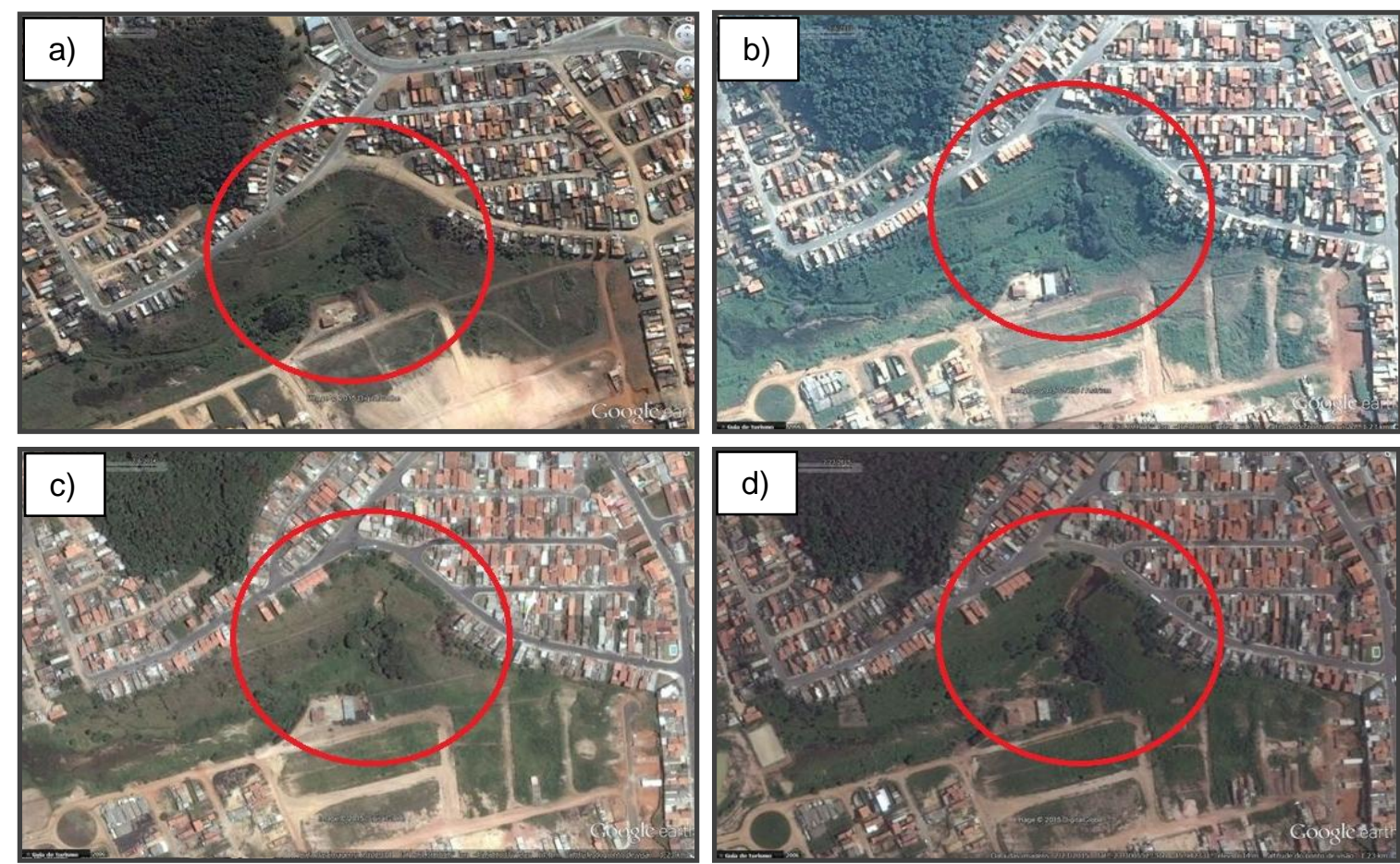

Figura 5. 9- Imagens do Google Earth com a evolução da voçoroca em diferentes períodos: a) setembro/2008; b) maio/2013; c) fevereiro/2014 e d) fevereiro/2015. O círculo em vermelho está representado na Figura 5.10. 
Apesar de não apresentar voçoroca, a análise do mapa de diferença das áreas de contribuição indicou considerável aumento de fluxo na encosta urbana destacada nas Figuras 5.12 e 5.13. Alguns pontos coletados ao longo da encosta foram analisados e comparados com pontos de voçorocas.

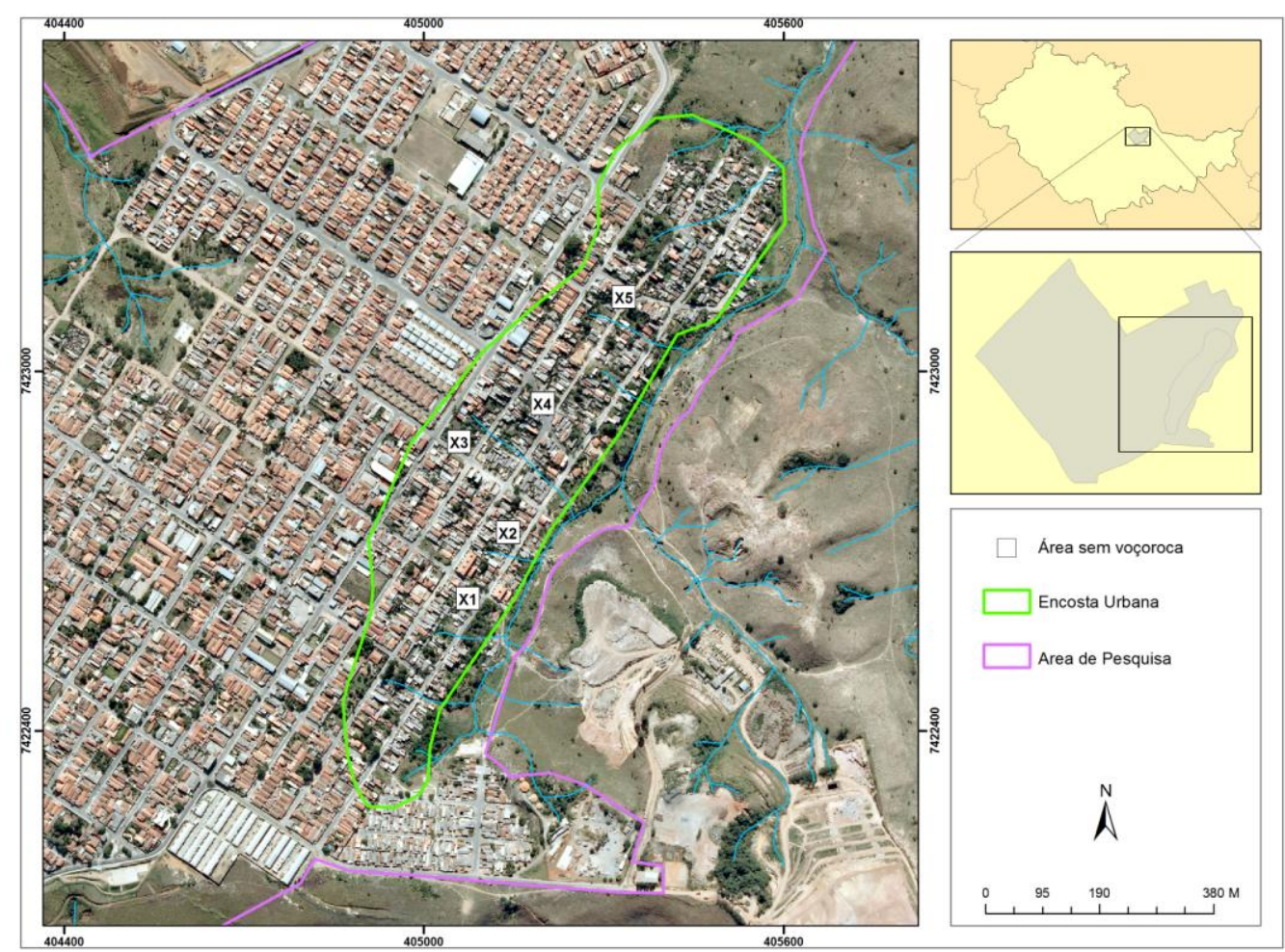

Figura 5. 10 - Fotografia com destaque na encosta e pontos coletados para análise.

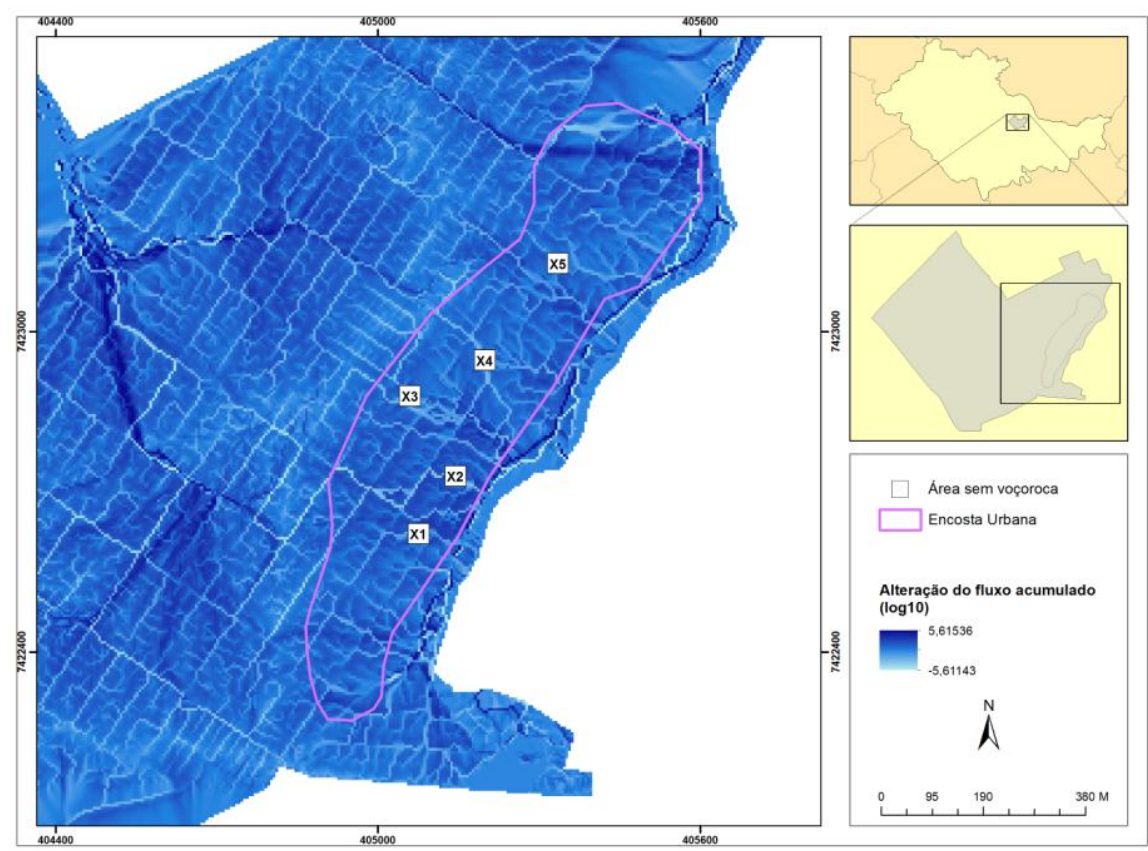

Figura 5. 11 - Mapa de alteração da área de contribuição da encosta urbana com pontos coletados para análise. 
Os pontos analisados apresentaram valor de declividade média similar ao de áreas com voçorocas e o aumento da área de contribuição foi elevado, de uma a duas ordens de grandeza (Tabela II). Nota-se que a urbanização ocorreu de forma intensa, ocupando inclusive áreas próximas a rede de drenagem. Esse padrão de ocupação faz com que o fluxo seja transportado diretamente para a rede de drenagem, normalmente sem causar erosões por conta da impermeabilização causada pelas edificações e pavimentações, que dificulta o transporte de sedimentos da superfície do solo.

Tabela II - Valores de área de contribuição e declividade dos pontos da encosta urbana (Figura 5.11)

\begin{tabular}{|c||c||c||c||}
\hline \hline Ponto & $\begin{array}{c}\text { Área de contribuição } \\
\text { (pré-urbano) }\end{array}$ & $\begin{array}{c}\text { Área de contribuição } \\
\text { (pós-urbano) }\end{array}$ & $\begin{array}{c}\text { Declividade } \\
\text { (pré-urbana) }\end{array}$ \\
\hline \hline X1 & 2,3976 & 3,3326 & 13,35 \\
\hline \hline X2 & 2,4442 & 4,1914 & 11,02 \\
\hline \hline X3 & 2,1941 & 3,4826 & 15,32 \\
\hline \hline X4 & 1,8969 & 2,8551 & 13,48 \\
\hline \hline X5 & 1,9048 & 2,6214 & 17,34 \\
\hline \hline \multicolumn{3}{|c||}{} \\
\hline \multicolumn{2}{|c|}{ Declividade média } \\
\hline
\end{tabular}




\section{6 - CONSIDERAÇÕES FINAIS}

A metodologia desenvolvida no trabalho permitiu avaliar a influência das modificações da rede de drenagem devido aos processos de urbanização no desenvolvimento de voçorocas. A análise de alterações na dinâmica do fluxo requer a elaboração e comparação de modelos hidrológicos consistentes de diferentes períodos. Em áreas com a urbanização consolidada, o desafio está na elaboração de modelos que simulem esse cenário antes da implantação dos elementos urbanos. A aplicação de técnicas fotogramétricas a partir de restituições e visualização tridimensional de fotografias aéreas com alta resolução espacial possibilitou a obtenção de um MDT que representa a topografia do relevo antes da urbanização.

O módulo MATCH-T DSM se destacou como importante ferramenta na extração de MDS. O DTMaster permitiu a edição do MDS para a elaboração do MDT, a partir de diversas ferramentas de filtragens, interpolações e visualizações da nuvem de pontos. Ambos módulos do sistema fotogramétrico INPHO tiveram grande importância na qualidade dos modelos digitais e dos mapas de área de contribuição.

A quantificação das informações relacionadas à superfície da área de estudo possibilitou a análise das modificações ocorridas na dinâmica hidrológica. Isso permitiu a análise dos mapas de área de contribuição dos períodos pré e pós-urbano e demonstrou forte relação entre o aumento de fluxo após a implantação dos elementos urbanos e o desenvolvimento de voçorocas. Isso corrobora com o resultado obtido por Carvalho Júnior et al. (2010), pela capacidade matemática de quantificação de elementos e comportamentos em determinada região, e destaca a importância do uso de modelos digitais consistentes utilizando técnicas aerofotogramétricas. As modificações na dinâmica hidrológica ocorridas na encosta urbana indicam um aumento do volume de fluxo diretamente para a rede de drenagem, o que pode ocasionar processos erosivos no entorno das áreas consolidadas ou mesmo na rede de drenagem.

O método aplicado de filtragens e suavizações foi realizado no trabalho para simulação do cenário pré-urbano, porém, a metodologia pode ser aplicada também de maneira inversa, simulando o cenário pós-urbano (MDS), através de inserções de cotas altimétricas representando elementos urbanos a partir de edições da nuvem de pontos do MDT.

Estudos das modificações na dinâmica hidrológica associados à urbanização são de extrema importância para compreensão do comportamento e desenvolvimento de processos erosivos em ambientes urbanos. Eles permitem o planejamento da redistribuição do fluxo, uma das medidas fundamentais para evitar novos processos erosivos. 


\section{REFERÊNCIAS}

AB'SÁBER, A. N. The Natural Organization of Brazilian Inter- and Subtropical Landscapes. Revista do Instituto Geológico, São Paulo, v. 21, n. 1-2, p. 57-70, 2000. Disponível em: <http://ppegeo.igc.usp.br/pdf/rig/v21n1-2/v21n1-2a05.pdf>. Acesso em: 08 nov. 2014.

ALMEIDA, F. F. Fundamentos geológicos do relevo paulista. Boletim Instituto Geográfico e Geológico. n. 41, São Paulo, 1964.

BERTONI, J.; LOMBARDI NETO, J. Conservação do solo. São Paulo: Ícone, 1990.

BIGARELLA, J. J.; BECKER, R. D.; SANTOS, G. F. Controle de erosão urbana e periurbana. In: Estrutura e origem das paisagens tropicais e subtropicais. 2. ed. Florianópolis: Editora da UFSC, 2007. v. 3.

BISTRICHI, C. A.; CAMPANHA, V. A.; SAAD, A. R.; ETCHEBEHERE, M. L. D. C.; SILVA, R. B. Perfil geoeconômico mineral do Município de Jacareí, SP. Revista Geociências - UnG, São Paulo, v. 1, .n. 3, p. 62-71, dez. 1996.

BOTELHO, R. G. M. Bacias hidrográficas urbanas. In: GUERRA, A. J. T. (Org.). Geomorfologia urbana. Rio de Janeiro: Bertrand Brasil, 2011.

; SILVA, A. S. Bacia hidrográfica e qualidade ambiental. In: GUERRA, A. J. T.; VITTE, A. C. (Orgs.). Reflexões sobre a Geografia Física no Brasil. 3. ed. Rio de Janeiro: Bertrand Brasil, 2010.

BOOTH, D. B. Urbanization and the natural drainage system - impacts, solutions, and prognoses. The Northwest Environmental Journal, v. 7. n. 1, p. 93-118, 1991.

CARDOSO NETO, A. Sistemas urbanos de drenagem. 2010. Disponível em: $<$ http://www.ana.gov.br/AcoesAdministrativas/CDOC/ProducaoAcademica/Antonio\%20Cardo so\%20Neto/Introducao_a_drenagem_urbana.pdf>. Acesso em: 12 dez. 2014.

CARVALHO JÚNIOR, O. A.; GUIMARÃES, R. F.; FREITAS, L. F.; GOMES-LOEBMANN, D.; GOMES, R. A. T.; MARTINS, E. S.; MONTGOMERY, D. R. Urbanization impacts upon catchment hydrology and gully development using mutli-temporal digital elevation data analysis. Earth Surface Processes and Landforms, v. 35, n. 5, p. 611-617, 2009.

CARVALHO, J. D.; DINIZ, N. Cartilha de Erosão. Projeto Pronex "Prevenção e recuperação de áreas potencias de degradação por processo de erosão superficial, profunda e interna no Centro Oeste", Brasília. Universidade de Brasília: FINATEC, 2007. 34 p. $3^{\mathrm{a}} \mathrm{ed}$. 
COLUMBUS, N.; MARIANO, I. B.; TEISSEDRE, J. M. Desenvolvimento de água subterrânea na região do Vale do Paraíba. In: Congresso Brasileiro de Águas Subterrâneas, 1, 1980, Recife. Anais... Recife: [s.n.], p. 229-302.

CONTI, J. B. Circulação secundária e efeito orográfico na gênese das chuvas na região les nordeste paulista. 1975. 82 f. Tese (Doutorado) - Instituto de Geografia, Universidade de São Paulo, São Paulo, 1975.

Clima e meio ambiente. São Paulo: Atual, 1998.

COSTANTINO, D.; ANGELINI, M. G. Features and ground automatic extraction from airborne Lidar data. International Archives of the Photogrammetry, Remote Sensing and Spatial Information Sciences, Canada, v. XXXVIII, n. 5/W12, 2011.

FELGUEIRAS, C. A. Modelagem numérica de terreno. In: CÂMARA, G.; DAVIS, C.; MONTEIRO, A. M. V. Introdução à ciência da Geoinformação. 2001.

FERNANDES, F. L. Arcabouço estrutural e evolução da Bacia de Taubaté-SP. 1993. 147

f. Dissertação (Mestrado) - Universidade Federal de Ouro Preto, Ouro Preto, MG, 1993.

FOSTER, G. R.; YOUNG, R. A.; ROMKENS, M. J. M.; ONSTAD, C. A. Process of soil erosion by water. In: FOLLET, R. F. STEWART, B. A. (Eds.). Soil erosion and crop productivity. American Society of Agronomy. Crop Science Society of America. Soil Science Society of America. Wiscosin, 1985.

FREITAS JUNIOR, G.; MARSON, A. A.; Estudo comparado de biogeografia fisionômica caracterização da vegetação do Vale do Paraíba paulista nos anos de 1817 e 2007. In: Seminário de Recursos Hídricos da Bacia Hidrográfica do Paraíba do Sul: o Eucalipto e o Ciclo Hidrológico, 2007, Taubaté. Anais... Taubaté: [s.n.], P. 107-114.

FRITZEN, M.; BINDA, A. L. Alterações no ciclo hidrológico em áreas urbanas: cidade, hidrologia e impactos no ambiente. Ateliê Geográfico, Goiânia, v. 5, n. 3, 2011.

GRUEN, A.; LI, Z. Automatic DTM generation from three-line-scanner (TLS) images. International Archives of Photogrammetry Remote Sensing and Spatial Information Sciences, Suiça, v. 34, n. 3/A, p. 131-137, 2002.

GUERRA, A. J. T. Encostas urbanas. In: GUERRA, A. J. T. (Org.) Geomorfologia urbana. Rio de Janeiro: Bertrand Brasil, 2011.

O início do processo erosivo. In: GUERRA, A. J. T.; SILVA, A. S.; BOTELHO, R. G. M.

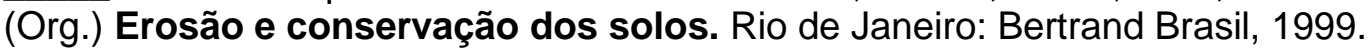


Processos erosivos nas encostas. In: GUERRA, A. J. T.; CUNHA, S. B. Geomorfologia: uma atualização de bases e conceitos. 2. ed. Rio de Janeiro: Bertrand Brasil, 1995.

GÜLCH, E. Advanced matching techniques for high precision surface and terrain models. Photogrammetric Week, p. 303-315, 2009.

GURNELL, A.; LEE, M.; SOUCH, C. Urban rivers: Hydrology, Geomorphology, Ecology and opportunities for change. Geography Compass, v. 1, n. 5, p. 1118-1137, set. 2007.

HAALA, N. The landscape of dense image matching algorithms. Stuttgart, 2013.

; HASTEDT, H.; WOLF, B. K.; RESSL, C.; BALTRUSCH, S. Digital Photogrammetric Camera Evaluation - Generation of Digital Elevation Models. Stuttgart, 2010.

HASUI, Y.; PONÇANO, W. L. Organização estrutural e evolução na Bacia de Taubaté. In: Congresso Brasileiro de Geologia, 30., 1978, Recife. Anais... Recife: SBG, 1978. v. 1, p. 368-381.

HOHLE, J. DEM generation using a digital large format frame camera. Photogrammetric Engineering \& Remote Sensing, v. 75, n. 1, p. 87-93, jan. 2009.

HORTON, R. E. Erosional development of streams and their drainage basins; hydrophysical approach to quantitative morphology. Geological Society of America Bulletin, v. 56, n. 3, p. 275-370, 1945.

HSIA, J. S.; NEWTON, I. A method for the automated production of digital terrain models using a combination of feature points, grid points, and filling back points. Photogrammetric Engineering \& Remote Sensing, v. 65, n. 6, p. 713-719, jun. 1999.

HUTCHINSON, M. F.; XU, T.; STEIN, J. A. Recent progress in the ANUDEM elevation gridding procedure. Geomorphometry, p. 19-22, 2011.

INSTITUTO DE PESQUISAS TECNOLÓGICAS DO ESTADO DE SÃO PAULO S/A - IPT. Geologia Tectônica, geomorfologia e sismologia regionais de interesse às usinas nucleares da praia de Itaorna. São Paulo, 1982. Disponível em: <https://searchworks.stanford.edu/view/1560322>. Acesso em: 15 nov. 2014.

; Geologia das folhas Jacareí (SF.23-Y-D-II-3), Tremembé (SF.23-Y-B-V-4), Taubaté (SF.23-YD-II-2) e Pindamonhangaba (SF.23-Y-D-VI-3): escala 1:50 000, Estado de São Paulo. São Paulo. (IPT. Relatório, 28.732). 1990. 
; Orientações para o combate à erosão no Estado de São Paulo - Síntese. São Paulo: IPT/DAEE. (IPT, Relatório 36071). 1997.

KAREL, W.; PFEIFER, N.; BRIESE, C. DTM quality assessment. ISPRS Techical Comission II Symposium, Vienna, 2006.

KERTZMAN, F. F.; OLIVEIRA, A. M. S.; SALOMÃO, F. X. T.; GOUVEIA, M. I. F. Mapa de erosão do ESTADO de São Paulo. Revista do Instituto Geológico, v. 16, n. esp. p. 31-36, 1995.

LEMAIRE, C. Aspects of the DSM production with high resolution images. International Archives of the Photogrammetry, Remote Sensing and Spatial Information Sciences, V. 37, n. B4, p. 1143-1146, 2008.

MARENGO, J. A.; ALVES, L. M.. Tendências hidrológicas da bacia do rio Paraíba do Sul. Revista Brasileira de Meteorologia, v. 20, n. 2, p. 215-226, 2005.

MARK, O.; WEESAKUL, S.; APIRUMANEKUL, C.; AROONNET, S. B.; DJORDJEVIC, S. Potential and limitations of 1D modelling of urban flooding. Journal of Hydrology, v. 299, n. 3-4, p. 284-299, dez. 2004.

NEARING, M. A.; FOSTER, G. R.; LANE, L. J.; FINKNER S. C. A process-based soil erosion model for USDA-water erosion prediction project technology. Transactions of the ASAE, $\mathrm{V}$. 32, n. 5, p. 1587-1593, set./out. 1989.

O'CALLAGHAN, J. F.; MARK, D. M. The extraction of drainage networks from digital elevation data. Computer Vision, Graphics and Image Processing, v. 28, n. 3, p. 328-344, dez. 1984.

OLIVEIRA, J. B. Solos do Estado de São Paulo: descrição das classes registradas no mapa pedológico. Campinas, SP: Instituto Agronômico, 1999. (Boletim Científico 45).

OLIVEIRA, M. A. T.; HERRMANN, M. L. P. Ocupação do solo e riscos ambientais na área conurbada de Florianópolis. In: GUERRA, A. J. T.; CUNHA, S. B. (Orgs.). Impactos ambientais urbanos no Brasil. 4. ed. Rio de Janeiro: Bertrand Brasil, 2006.

O'LOUGHLIN, E. M. Prediction of surface saturation zones in natural catchments by topographic analysis. Water Resources Research, v. 22, n. 5, p. 794-804, maio 1986.

POFF, N. L.; BLEDSOE, B. P.; CUHACIYAN, C. O. Hydrologic variation with land use across the contiguous United States: geomorphic and ecological consequences for stream ecosystems. Geomorphology, v. 79, n. 3-4, p. 264-285, set. 2006. 
PONÇANO, W. L.; PRANDINI, F. L. Boçorocas no Estado de São Paulo: uma revisão. In: IV Simpósio Nacional de Controle de Erosão, Marília, 1987. São Paulo. Anais... São Paulo: ABGE, 1987. p. 149- 177.

PORTO, R.; ZAHED, F. K.; TUCCI, C. E. M.; BIDONE, F. Drenagem urbana. In: TUCCI, C. E. M. (Org.) Hidrologia: ciência e aplicação. 3. ed. Porto Alegre: Editora da Universidade/UFRGS; ABRH, 2004.

PORTO, R.; ZAHED F., K.; TUCCI, C. E. M.; BIDONE, F. Drenagem urbana. In: TUCCI, C. E. M. (Org.) Hidrologia: ciência e aplicação. 4. ed. Porto Alegre: Editora da Universidade/UFRGS; ABRH, 2009.

PREFEITURA MUNICIPAL DE JACAREÍ: Disponível em: <http://www.jacarei.sp.gov.br/cidade/conheca-jacarei/historia>. Acesso em: 14 set. 2014.

PULIGHE, G.; FAVA, F. DEM extraction from archive aerial photos: accuracy assessment in areas of complex topography. European Journal of Remote Sensing, v. 46, p. 363-378, 2013.

QUINN, P.; BEVEN, K.; CHEVALLIER, P.; PLANCHON, O. The prediction of hillslope flow paths for distributed hydrological modelling using digital terrain models. Hydrological Processes, v. 5, n. 1, p. 59-79, jan./mar. 1991.

RAMOS, V. M.; GUIMARÃES, R. F.; REDIVO A. L.; GOMES, R. A. T.; FERNANDES, N. F.; CARVALHO JÚNIOR, O. A. Aplicação do Modelo SHALSTAB, em Ambiente ArcView, para o mapeamento de áreas susceptíveis a escorregamento raso na Região do Quadrilátero Ferrífero (MG). Espaço \& Geografia, v. 5, n. 1, p. 49-67, 2002.

RAMOS, V. M.; GUIMARÃES, R. F.; REDIVO, A. L.; CARVALHO JUNIOR, O. A.; FERREIRA, N. F.; GOMES, R. A. T. Avaliação de metodologias de determinação do cálculo de áreas de contribuição. Revista Brasileira de Geomorfologia, a. 4, n. 2, p. 41-49, 2003.

RESCHILIAN, P. R. O Vale do Paraíba no contexto da urbanização brasileira e a questão do desenvolvimento regional. Revista de Ciências Humanas, Taubaté, v. 11, n. 1, p. 25-32, jan./jun. 2005.

RIBEIRO, J. C.; Fotogrametria digital. 2002. Disponível em: <http://www2.esalq.usp.br/departamentos/leb/disciplinas/Topo/LER5831/Angulo/fotogramdig 2.pdf>. Acesso em: 22 out. 2014.

RICCOMINI, C. O rift continental do sudeste do Brasil. 1989. 304 f. Tese (Doutorado) Instituto de Geociências, Universidade de São Paulo, São Paulo, 1989. 
ROSS, J. L. S.; MOROZ, I. C. Mapa Geomorfológico do Estado de São Paulo. Revista do Departamento de Geografia, v. 10, p. 41-58, 2011. Disponível em: <http://www.revistas.usp.br/rdg/article/view/53703>. Acesso em: 22 set. 2014.

SÃO PAULO (Estado). Departamento de Águas e Energia Elétrica. Plano Estadual de Recursos Hídricos 2004-2007. São Paulo, 2005. Disponível em: <http://www.daee.sp.gov.br/acervoepesquisa/perh/perh2204_2207/perh20042007.htm>.

Acesso em: 28 set. 2014.

SPIX, J. B.; MARTIUS, C. F. P. Viagem pelo Brasil: 1817-1820. São Paulo: Edusp e Belo Horizonte: Itatiaia, 1981.

TARBOTON, D. G. A new method for the determination of flow directions and upslope areas in grid digital elevation models. Water Resources Research, v. 33, p. 309-319, 1997.

TEMBA, Plínio. Fundamentos da Fotogrametria. Departamento de Cartografia. Universidade Federal de Minas Gerais, Belo Horizonte, 2000.

TUCCI, C. E. M. Águas urbanas. Estudos Avançados, v. 22, n. 63, p. 97-112, 2008. Disponível em: <http://www.scielo.br/pdf/ea/v22n63/v22n63a07.pdf>. Acesso em: 18 set. 2014.

Plano diretor de drenagem urbana: princípios e concepção. Revista Brasileira de Recursos Hídricos, v. 2, n. 2, p. 5-12, jul./dez. 1997. Disponível em: <http://rhama.net/download/artigos/artigo2.pdf>. Acesso em: 18 set. 2014.

; COLLISCHONN, W. Drenagem urbana e controle de erosão. In: ; MARQUES, D. M. Avaliação e controle da drenagem urbana. Porto Alegre: EdUFRGS, 2000. v. 1.

VALERIANO, M. M.; CARVALHO JÚNIOR, O, A.. Geoprocessamento de modelos digitais de elevação para mapeamento da curvatura horizontal em microbacias. Revista Brasileira de Geomorfologia, a. 4, n. 1, p. 17-29, 2003.

VICTOR, M. A. M.; CAVALLI, A. C.; GUILLAUMON, J. R.; FILHO, R. S. Cem anos de devastação: revisitada 30 anos depois/Ministério do Meio Ambiente. Secretaria de Biodiversidade e Florestas. Brasília, 2005.

WEIDNER, U.; FÖRSTNER, W. Towards automatic building reconstruction from high resolution digital elevation models. ISPRS Journal, v. 50, n. 4, p. 38-49, 1995. 